\title{
De arbeidsmarkt voor HBO-technici
}

Citation for published version (APA):

Smits, W., \& Borghans, L. (1996). De arbeidsmarkt voor HBO-technici. Researchcentrum voor Onderwijs en Arbeidsmarkt, Faculteit der Economische Wetenschappen. ROA Reports No. 14 https://doi.org/10.26481/umarep.1996014

Document status and date:

Published: 01/01/1996

DOI:

10.26481/umarep.1996014

Document Version:

Publisher's PDF, also known as Version of record

\section{Please check the document version of this publication:}

- A submitted manuscript is the version of the article upon submission and before peer-review. There can be important differences between the submitted version and the official published version of record.

People interested in the research are advised to contact the author for the final version of the publication, or visit the DOI to the publisher's website.

- The final author version and the galley proof are versions of the publication after peer review.

- The final published version features the final layout of the paper including the volume, issue and page numbers.

Link to publication

\footnotetext{
General rights rights.

- You may freely distribute the URL identifying the publication in the public portal. please follow below link for the End User Agreement:

www.umlib.nl/taverne-license

Take down policy

If you believe that this document breaches copyright please contact us at:

repository@maastrichtuniversity.nl

providing details and we will investigate your claim.
}

Copyright and moral rights for the publications made accessible in the public portal are retained by the authors and/or other copyright owners and it is a condition of accessing publications that users recognise and abide by the legal requirements associated with these

- Users may download and print one copy of any publication from the public portal for the purpose of private study or research.

- You may not further distribute the material or use it for any profit-making activity or commercial gain

If the publication is distributed under the terms of Article $25 \mathrm{fa}$ of the Dutch Copyright Act, indicated by the "Taverne" license above, 


\title{
De arbeidsmarkt voor HBO-technici
}

\author{
ROA-R-1996/14
}

\section{Wendy Smits}

Lex Borghans

Researchcentrum voor Onderwijs en Arbeidsmarkt

Faculteit der Economische Wetenschappen en Bedrijfskunde Universiteit Maastricht

Maastricht, november 1996 
ISBN 90-5321-195-0 


\section{Inhoud}

Bladzijde

Voorwoord

1 Inleiding

2 De vraag naar technisch opgeleiden op HBO-niveau 5

2.1 Inleiding 5

2.2 Methodiek ROA-arbeidsmarktprognoses 5

2.3 De arbeidsmarkt voor HBO-technici, 1990-1994 8

2.4 Verwachte arbeidsmarktontwikkelingen tot $2000 \quad 18$

3 De werkgelegenheid voor HBO-technici naar bedrijfssector 23

$\begin{array}{ll}3.1 \text { Inleiding } & 23\end{array}$

3.2 De werkgelegenheid naar bedrijfssector 23

3.3 Conjunctuurgevoeligheid van de werkgelegenheid 29

4 HBO-technici werkzaam buiten de techniek 35

$\begin{array}{ll}4.1 \text { Inleiding } & 35\end{array}$

4.2 De verdeling van de werkgelegenheid over technische en
niet-technische beroepen

4.3 De arbeidsmarktpositie van technisch opgeleiden werkzaam $\begin{array}{ll}\text { buiten de techniek } & 38\end{array}$

5 Conclusies $\quad 49$

$\begin{array}{ll}\text { Literatuur } & 55\end{array}$

$\begin{array}{ll}\text { Appendix } 1 & 57\end{array}$

$\begin{array}{ll}\text { Appendix } 2 & 59\end{array}$

$\begin{array}{ll}\text { Appendix } 3 & 61\end{array}$ 



\section{Voorwoord}

Hoewel er geluiden opgingen dat er sprake was van tekorten aan technisch opgeleiden, bleek uit de HBO-Monitor - een jaarlijkse enquête onder afgestudeerden van het $\mathrm{HBO}$ - dat de werkloosheid onder afgestudeerden van de technische richtingen in 1993 en 1994 hoger was dan gemiddeld voor het HBO. Voor de HBO-raad vormde dit de aanleiding het Researchcentrum voor Onderwijs en Arbeidsmarkt (ROA) te verzoeken nader onderzoek te doen naar de arbeidsmarkt voor technisch opgeleiden. Dit rapport is het resultaat van dit onderzoek dat gebruik maakt van gegevens uit de vijf jaargangen van de HBO-Monitor die thans beschikbaar zijn en uit De arbeidsmarkt naar opleiding en beroep tot 2000, waarin vraag- en aanbodontwikkelingen op de arbeidsmarkt worden beschreven.

De auteurs danken Astrid Matheeuwsen en Wendy Montulet voor hun bijdrage aan dit onderzoek. 



\section{Inleiding}

Al enige jaren zijn er geluiden hoorbaar dat er een tekort zou zijn aan technisch opgeleiden. Toch blijkt de arbeidsmarktpositie van recent afgestudeerden van technische opleidingen op HBO-niveau de laatste jaren niet beter te zijn, en soms zelfs slechter dan de arbeidsmarktpositie van afgestudeerden van andere HBOrichtingen. Met name in 1993 en 1994 is de werkloosheid onder technisch opgeleiden relatief hoog (zie bijvoorbeeld Van de Loo e.a., 1996). Aan de ene kant lijkt er dus sprake te zijn van een tekort, terwijl aan de andere kant de arbeidsmarktpositie van technisch opgeleiden slechts matig is. Deze tegenstrijdigheid vormt de reden om nader onderzoek te doen naar de arbeidsmarkt voor technisch opgeleiden op HBOniveau.

In dit rapport wordt onderzocht bij welke technisch opleidingen op HBO-niveau er sprake was van een tekort en of dit tekort ook weerspiegeld werd door een ongunstige arbeidsmarktpositie van afgestudeerden van deze opleidingen. Tevens wordt getracht enkele verklaringen te vinden voor een hoge werkloosheid onder technisch opgeleiden, terwijl er tegelijkertijd sprake is van tekorten. Ten eerste kan een rol spelen dat de werkgelegenheid van technisch opgeleiden erg conjunctuurgevoelig is. Werkgevers nemen alleen technisch opgeleiden aan als de economische verwachtingen gunstig zijn. Technisch opgeleiden die op een ongunstig moment de arbeidsmarkt betreden vallen daardoor wellicht buiten de boot. Zij wijken, na enige tijd werkloos te zijn geweest, uit naar andere beroepen en komen niet meer terug in de techniek. Als de conjunctuur weer aantrekt ervaren werkgevers daardoor tekorten aan technisch opgeleiden.

Verder kan er sprake zijn van een sterke variatie in de kwaliteit van de afgestudeerden in de technische richtingen, al dan niet in combinatie met strenge selectiecriteria van werkgevers. Sommige afgestudeerden hebben in dat geval onvoldoende capaciteiten om in een technisch beroep te kunnen functioneren. Degenen die onvoldoende capaciteiten hebben, zijn langer werkloos en wijken uiteindelijk uit naar banen buiten de techniek of naar banen onder hun niveau. In dat geval is er sprake van negatieve selectie van technisch opgeleiden naar niet-technische beroepen (zie ook Borghans, De Grip en Smits, 1995).

Ten slotte is het mogelijk dat banen in de techniek niet aantrekkelijk genoeg zijn. Werkgevers passen het salaris en de andere arbeidsvoorwaarden niet aan de veranderde arbeidsmarkt aan. Afgestudeerden zoeken langer naar een baan in de hoop toch een gunstige baan in de techniek te vinden en wijken tenslotte uit naar beroepen buiten de techniek met gunstigere arbeidsvoorwaarden. Er is dan sprake van positieve selectie naar niet-technische beroepen. 


\section{Opbouw van het rapport}

De op sommige punten matige huidige arbeidsmarktpositie van afgestudeerden van technische opleidingen op HBO-niveau roept de vraag op of er wel echt sprake is van een tekort aan technisch opgeleiden. Als er inderdaad sprake is van tekorten, dan is het verder ook mogelijk dat deze tekorten zich alleen voordoen bij sommige technische richtingen in het HBO. In hoofstuk 2 wordt daarom eerst een beeld gegeven van vraag en aanbod op de arbeidsmarkt voor technisch opgeleiden op HBO-niveau voor de periode 1990-1994. Door vraag en aanbod per opleidingstype te confronteren wordt duidelijk bij welke opleidingstypes er in deze periode sprake was van tekorten. Vervolgens wordt gekeken naar de arbeidsmarktpositie van technisch opgeleiden die in deze periode zijn afgestudeerd. Ten slotte worden in dit hoofdstuk de verwachte ontwikkelingen op de arbeidsmarkt voor HBO-technici voor de periode 1995-2000 geschetst. De gegevens over de toekomstige ontwikkelingen zijn afkomstig uit De arbeidsmarkt naar opleiding en beroep tot 2000 (ROA 1995a,b).

In hoofstuk 3 zal worden ingegaan op de verdeling van de werkgelegenheid van HBO-technici over de verschillende bedrijfssectoren. Vervolgens wordt gekeken naar het aandeel van technisch opgeleiden op HBO-niveau in de werkgelegenheid van de verschillende bedrijfssectoren. Op basis hiervan kan worden nagegaan welke bedrijfssectoren de meeste knelpunten zullen ondervinden als gevolg van het verwachte tekort aan technisch opgeleiden. Daarnaast zal in hoofstuk 3 aandacht worden geschonken aan de conjunctuurgevoeligheid van de werkgelegenheid voor technisch opgeleiden. Gekeken zal worden in welke mate de werkloosheid onder recent afgestudeerde HBO-technici fluctueert met de conjunctuur.

In hoofdstuk 4 zal worden bekeken in welke mate technisch opgeleiden uitwijken naar niet-technische beroepen. Daarbij zal ook aandacht worden geschonken aan de verwachte vraagontwikkeling voor technisch opgeleiden vanuit niet-technische beroepen. Daarnaast zal de arbeidsmarktpositie van technisch opgeleiden werkzaam in niet-technisch beroepen worden vergeleken met de arbeidsmarktpositie van technisch opgeleiden die wel in de techniek werkzaam zijn. Gekeken wordt naar zaken als het loon, de mate van onderbenutting, een vaste aanstelling en deeltijdwerk. Ten slotte worden in hoofstuk 5 de belangrijkste conclusies getrokken en worden per opleidingstype de belangrijkste bevindingen gepresenteerd.

\section{Databronnen}

Voor het onderzoek is gebruik gemaakt van verschillende databronnen. Informatie over de arbeidsmarktpositie van HBO-schoolverlaters van technische opleidingen is gebaseerd op de HBO-monitor van de jaren 1991 tot en met 1995. Voor informatie over de vraag naar en het aanbod van technisch opgeleiden en over de conjuncturele ontwikkelingen is gebruik gemaakt van gegevens uit het ROA Informatiesysteem 
Onderwijs-Arbeidsmarkt, de Enquête Beroepsbevolking (EBB) van het CBS en gegevens van het Centraal Planbureau.

De informatie over vraag-aanbod-ontwikkelingen wordt gepresenteerd op het niveau van de ROA-opleidingstypes, die zijn gebaseerd op de Standaard Onderwijsindeling (SOI) van het $\mathrm{CBS}$. Om een goede vergelijking mogelijk te maken tussen deze gegevens en de informatie uit de HBO-Monitor is er voor gekozen om de gegevens op basis van de HBO-monitor ook op het niveau van de ROA-opleidingstypes te presenteren. Daarnaast worden, als er voldoende waarnemingen beschikbaar zijn, steeds ook de cijfers die betrekking hebben op de onderliggende opleidingsrichtingen gepresenteerd. Als het aantal waarnemingen onvoldoende is wordt dit in de tabellen aangegeven met een punt ${ }^{1}$. In appendix 1 wordt een overzicht gegeven van de ROA-opleidingstypes en de opleidingsrichtingen uit de HBO-Monitor die hier onder vallen. Overigens worden ook enkele opleidingsrichtingen die volgens de HBO-Monitor niet tot de sector techniek horen wel tot de technische opleidingstypes gerekend.

1. Het aantal waarnemingen per opleidingsrichting moet groter zijn dan 25. Bij de tabellen in hoofdstuk 4 geldt verder dat het aantal waarnemingen per beroepscategorie, technisch of niet-technisch, groter moet zijn dan 15. 



\section{De vraag naar technisch opgeleiden op HBO-niveau}

\subsection{Inleiding}

In dit hoofdstuk wordt een beeld gegeven van de knelpunten die zich in de periode 1990-1994 bij de rekrutering van technisch geschoold personeel op HBO-niveau hebben voorgedaan en van de verwachte toekomstige tekorten aan technici voor de periode 1995-2000. Ook zal worden ingegaan op de arbeidsmarktpositie van recent afgestudeerden van de technische opleidingen in deze periode. Het gaat daarbij om zaken als werkloosheid, onderbenutting, het percentage dat werkzaam is buiten de eigen vakrichting en het percentage dat een vast arbeidscontract heeft. In paragraaf 2.2 wordt allereerst een korte beschrijving gegeven van de methodiek van de arbeidsmarktprognoses uit het informatiesysteem onderwijs-arbeidsmarkt. In paragraaf 2.3 wordt vervolgens ingegaan op de arbeidsmarkt voor technisch opgeleiden in de periode 1990-1994. Ten slotte zal in paragraaf 2.4 worden ingegaan op de verwachte knelpunten bij de rekrutering van technisch personeel voor de periode 1995-2000.

\subsection{Methodiek ROA-arbeidsmarktprognoses}

Het ROA maakt arbeidsmarktprognoses voor zowel beroepen als opleidingen. Figuur 2.1 geeft een schematisch overzicht van het prognosemodel van het informatiesysteem Onderwijs-Arbeidsmarkt ${ }^{2}$. De uitbreidingsvraag geeft de verwachte werkgelegenheidsontwikkeling in een beroepsklasse of opleidingstype. Het uitgansgspunt van de uitbreidingsvraagprognoses vormen de bedrijfssectorprognoses van het Centraal Planbureau (CPB). Het CPB maakt prognoses van de werkgelegenheid per bedrijfssector op basis van het Athena-model (CPB, 1990). Binnen een bedrijfssector kunnen echter ook verschuivingen optreden in de beroepenstructuur. Op basis van het ROA-beroepenmodel wordt de vraag naar arbeid per beroepsklasse voorspeld. In dit model is de werkgelegenheidsontwikkeling per beroepsklasse afhankelijk van de sectorale werkgelegenheidsontwikkeling en van ontwikkelingen in de beroepenstructuur per sector. Daarnaast wordt ook rekening gehouden met ontwikkelingen in de productiviteit en bezettingsgraad per sector. Het beroepenmodel is geschat op basis van de Arbeidskrachtentellingen (AKT) en de Enquête Beroepsbevolking (EBB) van het Centraal Bureau voor de Statistiek (CBS) van de jaren 1979 tot en met 1994.

2. In Borghans, e.a (1995) wordt de methodiek van de arbeidsmarktprognoses meer in detail besproken. 
Figuur 2.1

Globale opzet prognosemodel ROA-informatiesysteem onderwijs-arbeidsmarkt

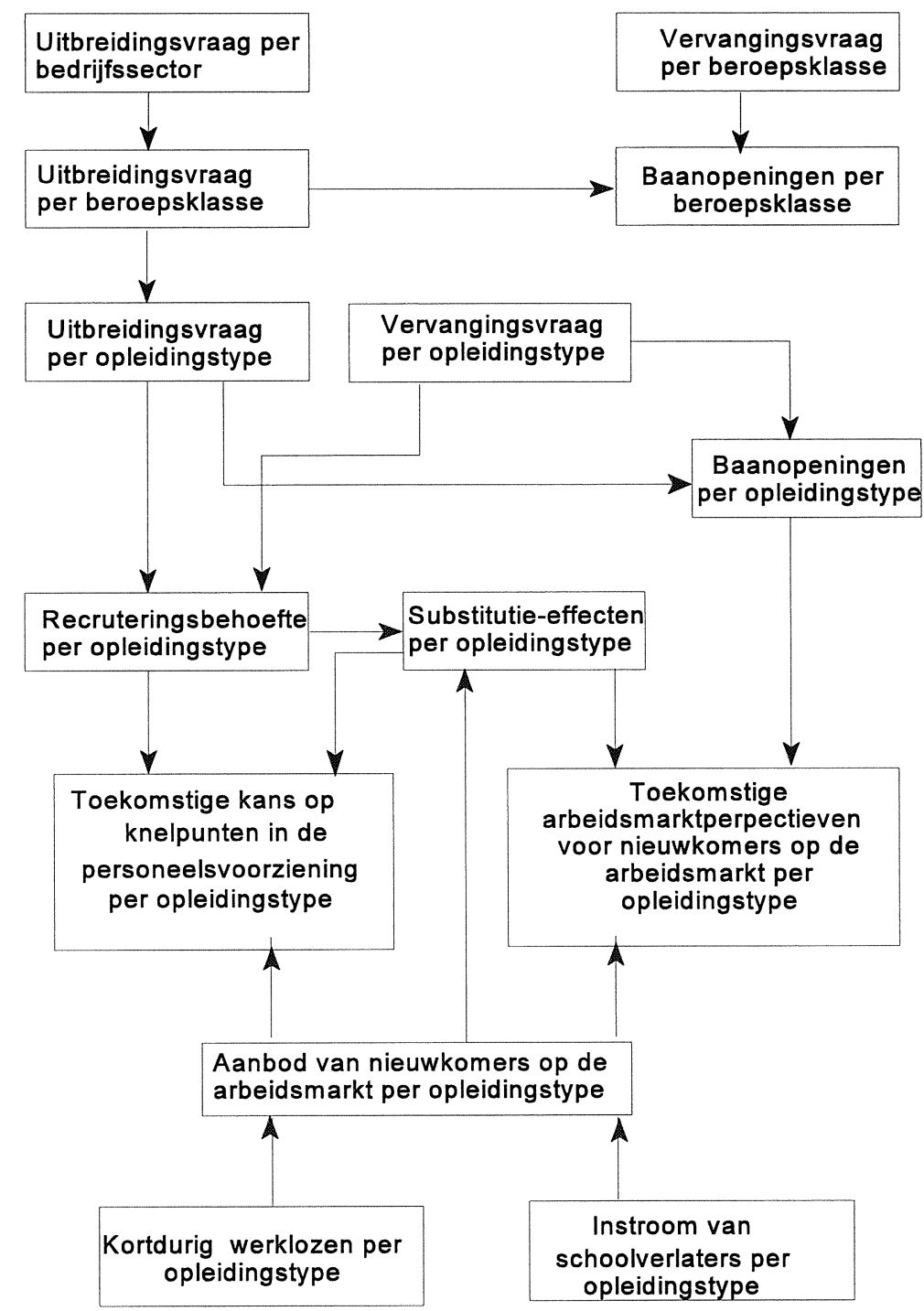

De vraag per beroepsklasse kan soms alleen worden opgevuld door mensen met een specifieke opleidingsachtergrond, maar vaak ook door mensen met een sterk uiteenlopende opleidingsachtergrond. Het ROA-opleidingenmodel vertaalt de verwachte uitbreidingsvraag per beroep naar een vraag per opleidingstype. Dat gebeurt op basis van de verdeling van de werkgelegenheid per opleidingstype over de beroepsklasse. Voor deze verdeling wordt wederom gebruik gemaakt van de EBB. 
In het opleidingenmodel wordt tevens rekening gehoudingen met verwachte werkgelegenheidsverschuiving als gevolg van 'upgrading'. Door de toenemende complexiteit van veel beroepen worden de opleidingseisen voor deze beroepen steeds hoger.

Naast de uitbreidingsvraag is ook de vervangingsvraag van belang voor nieuwkomers op de arbeidsmarkt. De vervangingsvraag is de vraag naar nieuwkomers die ontstaat vanwege pensionering, arbeidsongeschiktheid, tijdelijke terugtrekking van de arbeidsmarkt, beroepsmobiliteit e.d. Er is overigens alleen sprake van vervangingsvraag als het vertrek van een werknemer ook leidt tot een vacature. Als iemand die vertrekt niet wordt vervangen, bijvoorbeeld omdat een bedrijf moet inkrimpen, is er wel sprake van uitstroom maar niet van vervangingsvraag. De vervangingsvraag wordt voorspeld door een model dat op basis van de jaarlijkse veranderingen in de omvang van de werkgelegenheid per cohort uitstroomparameters per leeftijdscategorie bepaalt. Deze uitstroomparameters worden voor mannen en vrouwen afzonderlijk berekend. Door deze uitstroomparameters te combineren met de actuele leeftijdsopbouw van de beroepsbevolking, de bevolkingsprognoses van het CBS en de prognoses voor de participatiegraad van het CPB wordt een prognose verkregen van de toekomstige vervangingsvraag.

De uitbreidingsvraag en de vervangingsvraag geven samen de totale vraag naar nieuwkomers, ofwel de baanopeningen voor nieuwkomers. Als er sprake is van krimpende werkgelegenheid voor een opleidingstype dan is alleen sprake van baanopeningen als gevolg van de vervangingsvraag. Tegenover deze totale vraag naar niewkomers staat het verwachte aanbod van nieuwkomers. Het verwachte aanbod bestaat uit de toekomstige instroom van schoolverlaters op de arbeidsmarkt en de kortdurige werklozen aan het begin van de prognoseperiode. Daarbij is verondersteld dat alleen personen die korter dan een jaar werkloos zijn, serieuze concurrenten zijn voor schoolverlaters.

Uitgangspunt voor de instroomprognoses vormt de Referentieraming 1995 van het Ministerie van Onderwijs, Cultuur en Wetenschappen. De referentieraming geeft prognoses voor onder andere de instroom in het onderwijs, het aantal leerlingen en studenten en het aantal gediplomeerden voor het voltijds- en deeltijdonderwijs. Het ROA verbijzondert deze prognoses met behulp van gegevens van onder andere het CBS naar de ROA-opleidingsindeling. Deze indeling heeft een lager aggregatieniveau dan de indeling die wordt gehanteerd in de referentieraming. Op basis van aanvullende gegevens wordt tevens een schatting gemaakt van de arbeidsmarktinstroom uit het niet-reguliere onderwijs.

De uitbreidingsvraag en de vervangingsvraag geven samen de rekruteringsbehoefte per opleidingstype. De arbeidsmarktinstroom en het aanbod van kortdurige werklozen vormen tezamen het totale aanbod per opleidingstype. Discrepanties tussen vraag en aanbod leiden overigens niet zonder meer tot werkloosheid of openstaande 
vacatures. Als er sprake is van een tekort bij een bepaald opleidingstype dan kunnen werkgevers er immers toe overgaan om schoolverlaters uit een andere richting aan te nemen. Dit leidt in principe wel tot knelpunten in de personeelsvoorziening, omdat de werkgever meer inspanningen zal moeten verrichten om mensen te werven, beter zal moeten belonen of aanvullende scholing zal moeten geven. Een consequentie hiervan is dat een tekort bij de ene richting leidt tot extra vraag bij andere richtingen. Omgekeerd zal een aanbodoverschot van schoolverlaters uit een gegeven richting ook leiden tot een vraagafname bij andere (aanverwante) richtingen. Als er sprake is van een aanbodoverschot in een bepaalde richting dan zullen schoolverlaters uit deze richting immers vaak genoegen nemen met lagere Ionen. Zij worden daarom aantrekkelijker voor werkgevers. Werkgevers zullen dan meer schoolverlaters uit deze richting aannemen en minder schoolverlaters uit aanverwante richtingen. $\mathrm{Bij}$ het bepalen van de knelpunten in de personeelsvoorziening wordt ook rekening gehouden met de toe- of afname van de vraag als gevolg van een tekort of een overschot bij andere richtingen. Deze vraag wordt de passieve substitutievraag genoemd.

De indicator toekomstige knelpunten in de personeelsvoorziening (ITKP) geeft een indicatie van de verwachte discrepantie tussen vraag en aanbod voor een opleidingstype. Als de indicator kleiner dan 1 is betekent dat dat de vraag groter is dan het aanbod.

\subsection{De arbeidsmarkt voor HBO-technici, 1990-1994}

Om een beeld te krijgen van de recente ontwikkelingen op de arbeidsmarkt voor de technische opleidingen op HBO-niveau is een schatting gemaakt van de uitbreidingsvraag, de vervangingsvraag en de arbeidsmarktinstroom van schoolverlaters van deze opleidingen in de periode 1990-1994. De gevolgde methodiek komt overeen met de methodiek die gehanteerd is voor de ROA arbeidsmarktpognoses 19952000. Op basis van deze historische vraag- en aanbodcijfers is vervolgens per opleiding de indicator voor knelpunten in de personeelsvoorziening (ITKP) voor de periode 1990-1994 berekend.

\section{De vraag naar technisch opgeleiden}

Tabel 2.1 geeft de uitbreidingsvraag voor HBO-technici over de periode 1990-1994. Deze uitbreidingsvraag is niet per definitie gelijk aan de werkgelegenheidsontwikkeling voor HBO-technici. Het is de vraag, die bij onveranderde vraag-aanbod-verhoudingen op de markt voor HBO-technici, verwacht zou worden op grond van de feitelijke werkgelegenheidsontwikkelingen per beroepsklasse. Hierbij is zoals reeds is opgemerkt overigens wel rekening gehouden met 'upgrading' van de werkgelegenheid. Uit de tabel blijkt dat de uitbreidingsvraag, zowel absoluut als relatief gezien, het grootst was voor de opleidingen HBO elektrotechniek en technische 
informatica en HBO (weg-) en waterbouwkunde. De uitbreidingsvraag voor schoolverlaters uit de richting $\mathrm{HBO}$ werktuigbouwkunde was naar verhouding het laagst.

Tabel 2.1

Uitbreidingsvraag HBO-technici, 1990-1994

\begin{tabular}{lrrrll}
\hline Opleidingstype & Aantal & $\begin{array}{r}\text { Totaal } \\
\%\end{array}$ & $\begin{array}{r}\text { Gemiddeld } \\
\text { jaarlijks \% }\end{array}$ & Typering \\
\hline HBO technisch laboratorium & 1.400 & 6 & 1,4 & gemiddeld \\
HBO (weg- en water)bouwkunde & 3.500 & 11 & 2,6 & hoog \\
HBO werktuigbouwkunde & 1.100 & 4 & 1,0 & gemiddeld \\
HBO elektrotechniek en technische informatica & 4.700 & 13 & 3,1 & hoog \\
HBO technisch overig & 900 & 5 & 1,2 & gemiddeld \\
HBO haven en vervoer & 1.200 & 5 & 1,1 & gemiddeld \\
HBO medisch laboratorium & 800 & 5 & 1,2 & gemiddeld \\
HBO technische bedrijfskunde & 600 & 7 & 1,7 & gemiddeld \\
& & & & & \\
\hline
\end{tabular}

Bron: ROA

Tabel 2.2

Vervangingsvraag HBO-technici, 1990-1994

\begin{tabular}{lrrrll}
\hline & Aantal & $\begin{array}{r}\text { Totaal } \\
\%\end{array}$ & $\begin{array}{r}\text { Gemiddeld } \\
\text { jaarlijks \% }\end{array}$ & Typering \\
\hline HBO technisch laboratorium & & & & \\
HBO (weg- en water)bouwkunde & 2.200 & 9 & 2,1 & laag \\
HBO werktuigbouwkunde & 4.100 & 13 & 3,1 & gemiddeld \\
HBO elektrotechniek en technische informatica & 2.900 & 10 & 2,4 & gemiddeld \\
HBO technisch overig & 1.000 & 8 & 2,0 & laag \\
HBO haven en vervoer & 1.400 & 7 & 1,8 & erg laag \\
HBO medisch laboratorium & 2.700 & 11 & 2,6 & gemiddeld \\
HBO technische bedriffskunde & 1.000 & 6 & 1,4 & erg laag \\
& 600 & 6 & 1,5 & erg laag \\
\hline
\end{tabular}

Bron: ROA

Naast de uitbreidingsvraag komen er op de arbeidsmarkt ook banen vrij voor nieuwkomers vanwege vervangingsvraag die ontstaat door pensionering, arbeidsongeschiktheid, tijdelijke terugtrekking uit het arbeidsproces of beroepsmobiliteit. Uit tabel 2.2 blijkt dat de vervangingsvraag het hoogst is voor HBO (weg-en water)bouwkunde. Deze hogere vervangingsvraag is te verklaren uit de leeftijdsopbouw van werkenden met deze opleidingsachtergrond. Gemiddeld over 1993-1994 was slechts $15 \%$ van de werkende jonger dan 30 jaar terwijl $23 \%$ ouder dan 50 was. Ook de hogere vervangingsvraag voor HBO haven en vervoer wordt veroorzaakt door het hoge percentage werkenden dat ouder is dan 50 jaar. Gemiddeld over 1993-1994 was dat maar liefst $30 \%$ van alle werkenden ${ }^{3}$. De vervangingsvraag was juist erg laag voor de opleidingsrichtingen HBO medisch laboratorium en HBO

3. Zie ook tabel 3.5 uit ROA (1995b). 
technische bedrijfskunde. Deze opleidingenkenmerkenzich door een jonge leeftijdsopbouw.

De arbeidsmarktinstroom van technisch opgeleiden

Tegenover de twee vraagcategorieën - uitbreidingsvraag en vervangingsvraag staat het aanbod van nieuwkomers op de arbeidsmarkt. De verhouding tussen deze vraag- en aanbodontwikkeling bepaalt de arbeidsmarktpositie van de betreffende opleiding. De belangrijkste groep nieuwkomers betreft uiteraard de schoolverlaters die zich aanbieden op de arbeidsmarkt. Tabel 2.3 laat zien dat over de periode 1990-1994 de arbeidsmarktinstroom van schoolverlaters uit de richtingen HBO technische bedrijfskunde, HBO elektrotechniek en technische informatica en HBO werktuigbouwkunde hoog was. De arbeidsmarktinstroom van schoolverlaters uit de richting $\mathrm{HBO}$ haven en vervoer was daarentegen laag.

Tabel 2.3

Arbeidsmarktinstroom HBO-technici, 1990-1994

\begin{tabular}{lccccc}
\hline & Aantal & $\begin{array}{r}\text { Totaal } \\
\%\end{array}$ & $\begin{array}{r}\text { Gemiddeld } \\
\text { jaarlijks \% }\end{array}$ & Typering \\
\hline HBO technisch laboratorium & 3.000 & 12 & 3,0 & gemiddeld \\
HBO (weg- en water)bouwkunde & 4.100 & 13 & 3,1 & gemiddeld \\
HBO werktuigbouwkunde & 6.500 & 23 & 5,3 & hoog \\
HBO elektrotechniek en technische informatica & 8.600 & 24 & 5,6 & hoog \\
HBO technisch overig & 2.700 & 14 & 3,4 & gemiddeld \\
HBO haven en vervoer & 1.400 & 6 & 1,4 & laag \\
HBO medisch laboratorium & 2.200 & 12 & 3,0 & gemiddeld \\
HBO technische bedriffsunde & 3.000 & 33 & 7,3 & hoog \\
& & & & &
\end{tabular}

Bron: ROA

\section{Knelpunten in de personeelsvoorziening}

Tabel 2.3 geeft de indicator voor knelpunten in de personeelsvoorziening. Deze indicator geeft de verhouding tussen het aanbod en de vraag per opleidingstype. Naarmate de waarde van deze indicator lager is, is de kans op knelpunten in de personeelsvoorziening groter. Uit tabel 2.4 blijkt dat in de periode 1990-1994 niet bij alle opleidingstypen sprake lijkt te zijn geweest van knelpunten in de personeelsvoorziening. Er waren weinig knelpunten bij de richtingen $\mathrm{HBO}$ technisch laboratorium, HBO werktuigbouwkunde, HBO elektrotechniek en technische informatica, HBO medisch laboratorium en $\mathrm{HBO}$ technische bedrijfskunde. Hoewel de uitbreidingsvraag naar schoolverlaters uit de richting HBO elektrotechniek en informatica hoog was, lijkt dat niet tot veel knelpunten in de personeelsvoorziening te hebben geleid omdat ook de instroom van schoolverlaters uit deze richting hoog was. Ook bij HBO werktuigbouwkunde en $\mathrm{HBO}$ technische bedrijfskunde was de instroom groot genoeg in verhouding tot de vraag. Bij $\mathrm{HBO}$ technische bedrijfskunde speelt bovendien nog mee dat de vervangingsvraag erg laag was. Dat er geen aanbodtekorten waren 
bij HBO technisch laboratorium en HBO medisch laboratorium is te verklaren door de lage vervangingsvraag voor deze opleidingstypes.

Er waren wel veel knelpunten bij het opleidingstype HBO (weg- en water)bouwkunde. De uitbreidingsvraag was relatief hoog terwijl ook de vervangingsvraag veel hoger was dan bij de meeste andere technische opleidingen op HBO-niveau. De arbeidsmarktinstroom was daarentegen slechts gemiddeld. De ervaren knelpunten bij de weg- en waterbouwkunde zijn voor Rijkswaterstaat reeds aanleiding geweest het personeelsbeleid aan te scherpen (zie Borghans en Matheeuwsen, 1995). Als gevolg van de lage arbeidsmarktinstroom bij HBO haven en vervoer was er bij dit opleidingstype eveneens sprake van knelpunten.

Tabel 2.4

Kans op knelpunten in de personeelsvoorziening 1990-1994

\begin{tabular}{lll}
\hline & ITKP & $\begin{array}{l}\text { Typering kans } \\
\text { op knelpunten }\end{array}$ \\
\hline HBO technisch laboratorium & & klein \\
HBO (weg- en water)bouwkunde & 1.02 & groot \\
HBO werktuigbouwkunde & 0.89 & zeer klein \\
HBO elektrotechniek en technische informatica & 1.10 & klein \\
HBO technisch overig & 1.04 & groot \\
HBO haven en vervoer & 1.00 & klein \\
HBO medisch laboratorium & 0.94 & zeer klein \\
HBO technische bedrijfskunde & 1.05 & 1.21 \\
\hline
\end{tabular}

Bron: ROA

De arbeidsmarkpositie van recent afgestudeerde technici

Uit tabel 2.4 bleek dat er de afgelopen periode zeker niet bij alle technische richtingen op HBO-niveau sprake was van knelpunten in de personeelsvoorziening. De meeste knelpunten deden zich voor bij de opleidingstypen HBO (weg- en water)bouwkunde en $\mathrm{HBO}$ haven en vervoer. Bij $\mathrm{HBO}$ technische bedrijfskunde en $\mathrm{HBO}$ werktuigbouwkunde was daarentegen nauwelijks sprake van knelpunten. In deze paragraaf zal worden bekeken of deze verschillen ook terug te zien zijn in arbeidsmarktpositie van recent afgestudeerden in deze periode. Gekeken zal worden naar de ontwikkelingen in werkloosheid, zowel de werkloosheid op het enquêtemoment als de intredewerkloosheid, het percentage recent afgestudeerden dat wordt onderbenut, het percentage dat niet in de eigen vakrichting werkzaam is en het percentage dat een tijdelijke aanstelling heeft. Bij de HBO-Monitor worden afgestudeerden gemiddeld anderhalf jaar na afstuderen geënquêteerd. Gegevens over recent afgestudeerden in de enquêtejaren 1991 tot en met 1995 hebben betrekking op mensen die zijn afgestudeerd in de studiejaren 1989/1990 tot en met 1993/1994. Tabel 2.5 geeft het percentage recent afgestudeerden dat op het moment van de enquête als werkloos geregistreerd stond. Uit de tabel blijkt dat dit 
percentage sterk fluctueert van jaar tot jaar. De werkloosheid onder HBO'ers neemt sterk toe tussen 1991 en 1993. Vanaf 1994 daalt de werkloosheid weer. De werkloosheid verschilt ook sterk tussen de richtingen. Het blijkt dat de werkloosheid onder afgestudeerden uit de richtingen HBO (weg-en water)bouwkunde en HBO haven en vervoer inderdaad lager is dan de werkloosheid onder schoolverlaters uit de meeste andere technische richtingen. Wel neemt de werkloosheid ook voor afgestudeerden uit de richting HBO (weg- en water)bouwkunde toe in 1992 en 1993. Deze toename is het grootst bij de opleiding verkeerskunde. Dat wijst er op dat er vooral knelpunten waren bij de opleidingen bouwkunde en civiele techniek.

Tabel 2.5

Percentage recent afgestudeerden dat als werkloos geregistreerd staat

\begin{tabular}{|c|c|c|c|c|c|}
\hline \multirow[b]{2}{*}{ Opleidingstype/cluster } & \multicolumn{4}{|c|}{ Enquêtejaar } & \multirow[b]{2}{*}{1995} \\
\hline & 1991 & 1992 & 1993 & 1994 & \\
\hline $\begin{array}{l}\text { HBO technisch laboratorium } \\
\text { HLO Chemische laboratoriumopleiding } \\
\text { HLO Biologische laboratoriumopleiding }\end{array}$ & $\begin{array}{r}4 \\
3 \\
15\end{array}$ & $\begin{array}{r}10 \\
9 \\
14\end{array}$ & $\begin{array}{l}13 \\
12 \\
17\end{array}$ & $\begin{array}{l}17 \\
18\end{array}$ & $\begin{array}{r}14 \\
15 \\
5\end{array}$ \\
\hline $\begin{array}{l}\text { HBO (weg-en water)bouwkunde } \\
\text { HTO Bouwkunde } \\
\text { HTO Bouwtechnische bedrijfskunde } \\
\text { HTO Verkeerskunde } \\
\text { HTO Civiele techniek }\end{array}$ & $\begin{array}{l}3 \\
4 \\
0 \\
8 \\
0\end{array}$ & $\begin{array}{r}10 \\
11 \\
7 \\
10\end{array}$ & $\begin{array}{r}11 \\
12 \\
21 \\
6\end{array}$ & $\begin{array}{r}4 \\
3 \\
11 \\
5\end{array}$ & $\begin{array}{l}3 \\
2 \\
0 \\
6 \\
1\end{array}$ \\
\hline $\begin{array}{l}\text { HBO werktuigbouwkunde } \\
\text { HTO Werktuigbouwkunde } \\
\text { HTO Autotechniek } \\
\text { HNO Algemene operationele technologie (AOT) }\end{array}$ & $\begin{array}{r}9 \\
8 \\
10 \\
12\end{array}$ & $\begin{array}{r}12 \\
11 \\
8 \\
18\end{array}$ & $\begin{array}{l}20 \\
21 \\
20 \\
12\end{array}$ & $\begin{array}{r}13 \\
15 \\
14 \\
.\end{array}$ & $\begin{array}{l}6 \\
6 \\
2 \\
.\end{array}$ \\
\hline $\begin{array}{l}\text { HBO elektrotechniek en technische informatica } \\
\text { HTO Elektrotechniek } \\
\text { HTO Informatica }\end{array}$ & $\begin{array}{r}10 \\
11 \\
6\end{array}$ & $\begin{array}{r}16 \\
19 \\
7\end{array}$ & $\begin{array}{l}21 \\
23 \\
13\end{array}$ & $\begin{array}{r}15 \\
17 \\
9\end{array}$ & $\begin{array}{l}6 \\
6 \\
6\end{array}$ \\
\hline $\begin{array}{l}\text { HBO technisch overig } \\
\text { HTO Chemische technologie } \\
\text { HAS Levensmiddelentechnologie } \\
\text { HTO Technische natuurkunde }\end{array}$ & $\begin{array}{r}9 \\
10 \\
8 \\
10\end{array}$ & $\begin{array}{l}12 \\
14 \\
10 \\
11\end{array}$ & $\begin{array}{r}13 \\
15 \\
14 \\
7\end{array}$ & $\begin{array}{l}22 \\
26 \\
16 \\
20\end{array}$ & $\begin{array}{r}11 \\
13 \\
10 \\
6\end{array}$ \\
\hline HBO haven en vervoer & 4 & 0 & 3 & . & 3 \\
\hline HBO medisch laboratorium & 3 & 5 & 4 & 9 & 4 \\
\hline $\begin{array}{l}\text { HBO technische bedrijfskunde } \\
\text { HTO Opleiding bedrijfskader } \\
\text { HTO Logistiek (management) } \\
\text { HTO Technische bedrijfskunde } \\
\text { HEO/HTO Logistiek en Economie }\end{array}$ & $\begin{array}{l}4 \\
. \\
5 \\
5\end{array}$ & $\begin{array}{r}16 \\
11 \\
.\end{array}$ & $\begin{array}{l}10 \\
17 \\
19\end{array}$ & $\begin{array}{l}16 \\
14\end{array}$ & $\begin{array}{l}6 \\
6\end{array}$ \\
\hline $\begin{array}{l}\text { Totaal HBO technisch (excl. deeltijd) } \\
\text { Totaal HBO technisch (incl. deeltijd) } \\
\text { Totaal HBO }\end{array}$ & $\begin{array}{l}7 \\
7 \\
6\end{array}$ & $\begin{array}{l}12 \\
11 \\
10\end{array}$ & $\begin{array}{l}16 \\
15 \\
11\end{array}$ & $\begin{array}{r}14 \\
13 \\
9\end{array}$ & $\begin{array}{l}6 \\
6 \\
6\end{array}$ \\
\hline
\end{tabular}

Bron: ROA (HBO-Monitor) 
De werkloosheid onder afgestudeerden uit de richtingen $\mathrm{HBO}$ werktuigbouwkunde en HBO elektrotechniek en technische informatica en HBO technische bedrijfskunde is daarentegen tot en met 1994 hoger dan gemiddeld. Ook deze cijfers bevestigen het beeld dat er in de periode 1990-1994 weinig knelpunten in de personeelsvoorziening waren voor deze richtingen. In 1995 is de werkloosheid onder schoolverlaters uit genoemde richtingen gelijk aan het gemiddelde voor het HBO. Bij HBO elektrotechniek en technische informatica blijkt overigens vooral onder afgestudeerden HTO elektrotechniek de werkloosheid hoog te zijn. Onder afgestudeerden HTO informatica is de werkloosheid een stuk lager. Mogelijk zijn er bij deze opleiding dus wel wat knelpunten geweest bij de rekrutering van afgestudeerden. Bij het opleidingstype HBO werktuigbouwkunde zijn er geen opvallende verschillen in werkloosheid tussen de onderliggende opleidingen.

Tabel 2.6

Percentage werkzame recent afgestudeerden dat niet werkloos is geweest tijdens intredeperiode

\begin{tabular}{|c|c|c|c|c|c|}
\hline Opleidingstype/cluster & 1991 & 1992 & 1993 & 1994 & 1995 \\
\hline $\begin{array}{l}\text { HBO technisch laboratorium } \\
\text { HLO Chemische laboratoriumopleiding } \\
\text { HLO Biologische laboratoriumopleiding }\end{array}$ & $\begin{array}{l}74 \\
73 \\
82\end{array}$ & $\begin{array}{r}64 \\
63 \\
.\end{array}$ & $\begin{array}{l}56 \\
56\end{array}$ & $\begin{array}{l}49 \\
49\end{array}$ & $\begin{array}{l}46 \\
46 \\
51\end{array}$ \\
\hline $\begin{array}{l}\text { HBO (weg-en water)bouwkunde } \\
\text { HTO Bouwkunde } \\
\text { HTO Bouwtechnische bedrijfskunde }\end{array}$ & $\begin{array}{l}72 \\
73\end{array}$ & $\begin{array}{l}74 \\
71\end{array}$ & $\begin{array}{l}68 \\
67\end{array}$ & $\begin{array}{l}64 \\
64\end{array}$ & $\begin{array}{l}67 \\
61\end{array}$ \\
\hline $\begin{array}{l}\text { HTO Verkeerskunde } \\
\text { HTO Civiele techniek }\end{array}$ & $\begin{array}{l}55 \\
77\end{array}$ & $\begin{array}{l}62 \\
78\end{array}$ & $\begin{array}{l}43 \\
77\end{array}$ & $\begin{array}{l}56 \\
66\end{array}$ & $\begin{array}{l}79 \\
68\end{array}$ \\
\hline $\begin{array}{l}\text { HBO werktuigbouwkunde } \\
\text { HTO Werktuigbouwkunde } \\
\text { HTO Autotechniek } \\
\text { HNO Algemene operationele technologie (AOT) }\end{array}$ & $\begin{array}{l}66 \\
64 \\
63 \\
.\end{array}$ & $\begin{array}{l}53 \\
48 \\
61 \\
69\end{array}$ & $\begin{array}{l}54 \\
53 \\
53 \\
55\end{array}$ & $\begin{array}{l}52 \\
45 \\
54\end{array}$ & $\begin{array}{l}61 \\
60 \\
61\end{array}$ \\
\hline $\begin{array}{l}\text { HBO elektrotechniek en technische informatica } \\
\text { HTO Elektrotechniek } \\
\text { HTO Informatica }\end{array}$ & $\begin{array}{l}59 \\
61 \\
51\end{array}$ & $\begin{array}{l}51 \\
49 \\
56\end{array}$ & $\begin{array}{l}44 \\
39 \\
56\end{array}$ & $\begin{array}{l}46 \\
43 \\
54\end{array}$ & $\begin{array}{l}52 \\
48 \\
60\end{array}$ \\
\hline $\begin{array}{l}\text { HBO technisch overig } \\
\text { HTO Chemische technologie } \\
\text { HAS Levensmiddelentechnologie } \\
\text { HTO Technische natuurkunde }\end{array}$ & $\begin{array}{l}59 \\
69 \\
47 \\
53\end{array}$ & $\begin{array}{l}57 \\
64 \\
57 \\
41\end{array}$ & $\begin{array}{l}42 \\
41 \\
42\end{array}$ & $\begin{array}{l}43 \\
45 \\
44 \\
38\end{array}$ & $\begin{array}{l}50 \\
47 \\
59 \\
51\end{array}$ \\
\hline HBO haven en vervoer & 83 & 77 & 78 & . & 60 \\
\hline HBO medisch laboratorium & 70 & 67 & 73 & 54 & 52 \\
\hline $\begin{array}{l}\text { HBO technische bedrijfskunde } \\
\text { HTO Opleiding bedrijfskader } \\
\text { HTO Logistiek (management) }\end{array}$ & 60 & 55 & 55 & $\begin{array}{l}46 \\
46\end{array}$ & $\begin{array}{l}56 \\
63\end{array}$ \\
\hline $\begin{array}{l}\text { HTO Technische bedrijfskunde } \\
\text { HEO/HTO Logistiek en Economie }\end{array}$ & 59 & 52 & $\begin{array}{l}41 \\
56 \\
53\end{array}$ & $\begin{array}{l}44 \\
54\end{array}$ & $\begin{array}{l}53 \\
75\end{array}$ \\
\hline $\begin{array}{l}\text { Totaal HBO technisch (excl. deeltijd) } \\
\text { Totaal HBO technisch (incl. deeltijd) } \\
\text { Totaal HBO }\end{array}$ & $\begin{array}{l}65 \\
67 \\
71\end{array}$ & $\begin{array}{l}58 \\
61 \\
67\end{array}$ & $\begin{array}{l}54 \\
57 \\
66\end{array}$ & $\begin{array}{l}50 \\
54 \\
64\end{array}$ & $\begin{array}{l}56 \\
58 \\
65\end{array}$ \\
\hline
\end{tabular}

Bron: ROA (HBO-Monitor) 
Tabel 2.6 geeft het percentage van de werkzame afgestudeerden dat niet te maken heeft gehad met intredewerkloosheid. Voor het $\mathrm{HBO}$ als geheel daalt dit percentage van $71 \%$ in 1991 tot $65 \%$ in 1994 . Bij de technische opleidingen daalt dat percentage nog meer. Met name bij de opleidingstypes HBO technisch laboratorium en HBO medisch laboratorium is het percentage dat dat niet werkloos is geweest in de intredeperiode de afgelopen jaren sterk gedaald.

Tabel 2.7

Percentage recent afgestudeerden dat werk heeft waarvoor een opleidingniveau lager dan $\mathrm{HBO}$ vereist was

\begin{tabular}{|c|c|c|c|c|c|}
\hline \multirow[b]{2}{*}{ Opleidingstype/clusters } & \multicolumn{4}{|c|}{ Enquêtejaar } & \multirow[b]{2}{*}{1995} \\
\hline & 1991 & 1992 & 1993 & 1994 & \\
\hline $\begin{array}{l}\text { HBO technisch laboratorium } \\
\text { HLO Chemische laboratoriumopleiding } \\
\text { HLO Biologische laboratoriumopleiding }\end{array}$ & $\begin{array}{l}6 \\
7 \\
4\end{array}$ & $\begin{array}{l}9 \\
9 \\
.\end{array}$ & $\begin{array}{l}15 \\
15\end{array}$ & $\begin{array}{l}20 \\
20\end{array}$ & $\begin{array}{l}24 \\
23 \\
23\end{array}$ \\
\hline $\begin{array}{l}\text { HBO (weg-en water)bouwkunde } \\
\text { HTO Bouwkunde } \\
\text { HTO Bouwtechnische bedrijfskunde } \\
\text { HTO Verkeerskunde } \\
\text { HTO Civiele techniek }\end{array}$ & $\begin{array}{l}19 \\
23 \\
25 \\
13\end{array}$ & $\begin{array}{r}13 \\
17 \\
9 \\
9\end{array}$ & $\begin{array}{l}17 \\
21 \\
13 \\
13\end{array}$ & $\begin{array}{r}9 \\
11 \\
7 \\
5\end{array}$ & $\begin{array}{l}12 \\
10\end{array}$ \\
\hline $\begin{array}{l}\text { HBO werktuigbouwkunde } \\
\text { HTO Werktuigbouwkunde } \\
\text { HTO Autotechniek } \\
\text { HNO Algemene operationele technologie (AOT) }\end{array}$ & $\begin{array}{r}11 \\
10 \\
21 \\
8\end{array}$ & $\begin{array}{r}14 \\
13 \\
24 \\
8\end{array}$ & $\begin{array}{l}26 \\
24 \\
39 \\
28\end{array}$ & $\begin{array}{r}23 \\
20 \\
34 \\
.\end{array}$ & $\begin{array}{r}15 \\
13 \\
35 \\
.\end{array}$ \\
\hline $\begin{array}{l}\text { HBO elektrotechniek en technische informatica } \\
\text { HTO Elektrotechniek } \\
\text { HTO Informatica }\end{array}$ & $\begin{array}{r}12 \\
13 \\
7\end{array}$ & $\begin{array}{l}13 \\
14 \\
10\end{array}$ & $\begin{array}{l}20 \\
23 \\
11\end{array}$ & $\begin{array}{r}20 \\
25 \\
6\end{array}$ & $\begin{array}{r}12 \\
16 \\
4\end{array}$ \\
\hline $\begin{array}{l}\text { HBO technisch overig } \\
\text { HTO Chemische technologie } \\
\text { HAS Levensmiddelentechnologie } \\
\text { HTO Technische natuurkunde }\end{array}$ & $\begin{array}{l}5 \\
3 \\
9\end{array}$ & $\begin{array}{r}8 \\
7 \\
12 \\
7\end{array}$ & $\begin{array}{r}10 \\
9 \\
12 \\
.\end{array}$ & $\begin{array}{l}21 \\
20 \\
20 \\
28\end{array}$ & $\begin{array}{l}21 \\
21 \\
24 \\
17\end{array}$ \\
\hline HBO haven en vervoer & 21 & 44 & 19 & . & 32 \\
\hline HBO medisch laboratorium & 15 & 19 & 12 & 21 & 14 \\
\hline $\begin{array}{l}\text { HBO technische bedrijfskunde } \\
\text { HTO Opleiding bedrijfskader } \\
\text { HTO Logistiek (management) } \\
\text { HTO Technische bedrijfskunde } \\
\text { HEO/HTO Logistiek en Economie }\end{array}$ & $\begin{array}{r}15 \\
12 . \\
.\end{array}$ & 12 & $\begin{array}{l}15 \\
15 \\
34\end{array}$ & $\begin{array}{l}16 \\
42\end{array}$ & $\begin{array}{l}14 \\
23\end{array}$ \\
\hline $\begin{array}{l}\text { Totaal HBO technisch (excl. deeltijd) } \\
\text { Totaal HBO technisch (incl. deeltijd) } \\
\text { Totaal HBO }\end{array}$ & $\begin{array}{l}13 \\
13 \\
21\end{array}$ & $\begin{array}{l}13 \\
13 \\
21\end{array}$ & $\begin{array}{l}19 \\
19 \\
23\end{array}$ & $\begin{array}{l}19 \\
20 \\
24\end{array}$ & $\begin{array}{l}16 \\
16 \\
22\end{array}$ \\
\hline
\end{tabular}

Bron: ROA (HBO-Monitor)

Een slechte arbeidsmarktpositie van een opleiding uit zich, zoals reeds is opgemerkt, niet alleen in een hoge werkloosheid onder afgestudeerden van deze opleiding. Als er sprake is van een aanbodoverschot zullen afgestudeerden proberen om 
werk te vinden buiten hun eigen domein. Vaak accepteren ze dan beroepen op een lager functieniveau of in een andere vakrichting. Een hoog percentage schoolverlaters dat wordt onderbenut, of in een andere vakrichting werkzaam is, duidt daarom ook op een slechte arbeidsmarktpositie. Uit tabel 2.7 blijkt dat ruim $20 \%$ van de afgestudeerden van het $\mathrm{HBO}$, volgens eigen zeggen, in een beroep werkzaam is waarvoor het vereiste opleidingsniveau lager is dan HBO-niveau. Dit percentage schommelt niet zoveel tussen de verschillende enquêtejaren. Het percentage onderbenutting verschilt echter sterk tussen de onderscheiden opleidingstypen. Het percentage onderbenutting is met name erg hoog voor het opleidingstype HBO (weg- en water)bouwkunde. Dat is opvallend omdat juist bij dit opleidingstype sprake was van knelpunten in de personeelsvoorziening. Het blijkt echter dat ook hier dit hoge percentage voornamelijk is toe te schrijven aan de opleidingen HTO bouwkunde en HTO verkeerskunde. Bij de opleiding civiele techniek is het percentage onderbenutting veel lager. Bij HBO werktuigbouwkunde is het percentage onderbenutting aanvankelijk niet zo hoog, maar in 1993 neemt het percentage sterk toe. Uit tabel 2.5 bleek al dat in dat jaar ook de werkloosheid voor dit opleidingstype sterk toenam. In 1995 daalt het percentage onderbenutting bij dit opleidingstype weer. Voor HTO autotechniek is het percentage onderbenutting overigens veel hoger dan voor HTO werktuigbouwkunde. Bovendien blijft de onderbenutting bij HTO autotechniek ook in 1995 erg hoog. Bij HBO elektrotechniek en technische informatica neemt de onderbenutting van recent afgestudeerden eveneens sterk toe in 1993. Het blijkt echter dat dit hoge percentage onderbenutting bij dit opleidingstype vooral is toe te schrijven aan de opleiding HTO elektrotechniek en veel minder aan HTO informatica. Dat wijst er opnieuw op dat bij HTO informatica mogelijk wel sprake was van knelpunten. Het percentage dat wordt onderbenut lijkt sterk te schommelen bij het opleidingstype HBO haven en vervoer. De verschillen tussen de jaren zijn echter niet significant omdat het aantal waarnemingen voor dit opleidingstype erg klein is. $\mathrm{Bij} \mathrm{HBO}$ technische bedrijfskunde is het hoge percentage onderbenutting in 1994 en 1995 geheel toe te schrijven aan de opleidingen HTO opleiding voor bedrijfskader en HEO/HTO logistiek en economie. Bij de opleiding HTO technische bedrijfskunde is het percentage onderbenutting juist lager dan gemiddeld voor het $\mathrm{HBO}$.

Tabel 2.8 geeft vervolgens het percentage van de recent afgestudeerden dat zegt werkzaam te zijn in een andere vakrichting dan waarvoor men is opgeleid. Ook dit kan een uiting zijn van problemen om in het eigen vakgebied werk te vinden. Met name afgestudeerden uit de richting $\mathrm{HBO}$ bedrijfskunde werken vaak in een beroep dat qua richting niet aansluit op hun studie. Ook bij de opleidingstypes HBO elektrotechniek en Informatica en HBO werktuigbouwkunde is dit percentage relatief hoog. Opnieuw geldt hier overigens dat er verschillen zijn tussen de onderliggende richtingen. Zo is het percentage dat in een andere richting werkzaam is vooral hoog voor afgestudeerden van de opleiding autotechniek. Ook zijn afgestudeerden van opleiding HTO elektrotechniek in de meeste jaren vaker werkzaam buiten de eigen richtingen dan afgestudeerden van HTO informatica. Bij de opleidingstypen HBO 
(weg- en water)bouwkunde en HBO Haven en Vervoer is het percentage dat buiten de eigen vakrichting werkzaam is relatief laag. Aanvankelijk gold dat ook voor de opleidingstypen HBO technisch en HBO medisch laboratorium, maar vanaf 1993 stijgt het percentage dat buiten de vakrichting werkzaam is aanzienlijk.

Tabel 2.8

Percentage recent afgestudeerden dat werkzaam is buiten de eigen vakrichting

\begin{tabular}{|c|c|c|c|c|c|}
\hline \multirow[b]{2}{*}{ Opleidingstype/cluster } & \multicolumn{4}{|c|}{ Enquêtejaar } & \multirow[b]{2}{*}{1995} \\
\hline & 1991 & 1992 & 1993 & 1994 & \\
\hline $\begin{array}{l}\text { HBO technisch laboratorium } \\
\text { HLO Chemische laboratoriumopleiding } \\
\text { HLO Biologische laboratoriumopleiding }\end{array}$ & $\begin{array}{l}7 \\
8 \\
0\end{array}$ & $\begin{array}{l}5 \\
6 \\
0\end{array}$ & $\begin{array}{r}11 \\
12 \\
.\end{array}$ & $\begin{array}{r}13 \\
12 \\
.\end{array}$ & $\begin{array}{l}22 \\
21 \\
19\end{array}$ \\
\hline $\begin{array}{l}\text { HBO (weg-en water)bouwkunde } \\
\text { HTO Bouwkunde } \\
\text { HTO Bouwtechnische bedrijfskunde } \\
\text { HTO Verkeerskunde } \\
\text { HTO Civiele techniek }\end{array}$ & $\begin{array}{r}7 \\
7 \\
22 \\
2\end{array}$ & $\begin{array}{r}3 \\
2 \\
15 \\
2\end{array}$ & $\begin{array}{r}5 \\
5 \\
10 \\
4\end{array}$ & $\begin{array}{r}7 \\
8 \\
13 \\
5\end{array}$ & $\begin{array}{r}25 \\
3\end{array}$ \\
\hline $\begin{array}{l}\text { HBO werktuigbouwkunde } \\
\text { HTO Werktuigbouwkunde } \\
\text { HTO Autotechniek } \\
\text { HNO Algemene operationele technologie (AOT) }\end{array}$ & $\begin{array}{l}12 \\
10 \\
12 \\
.\end{array}$ & $\begin{array}{l}13 \\
11 \\
18 \\
19\end{array}$ & $\begin{array}{l}18 \\
15 \\
33 \\
25\end{array}$ & $\begin{array}{l}20 \\
18 \\
24 \\
.\end{array}$ & $\begin{array}{l}16 \\
15 \\
20 \\
.\end{array}$ \\
\hline $\begin{array}{l}\text { HBO elektrotechniek en technische informatica } \\
\text { HTO Elektrotechniek } \\
\text { HTO Informatica }\end{array}$ & $\begin{array}{r}13 \\
14 \\
7\end{array}$ & $\begin{array}{l}7 \\
9 \\
3\end{array}$ & $\begin{array}{l}19 \\
18 \\
23\end{array}$ & $\begin{array}{l}17 \\
19 \\
11\end{array}$ & $\begin{array}{l}14 \\
15 \\
13\end{array}$ \\
\hline $\begin{array}{l}\text { HBO technisch overig } \\
\text { HTO Chemische technologie } \\
\text { HAS Levensmiddelentechnologie } \\
\text { HTO Technische natuurkunde }\end{array}$ & $\begin{array}{r}10 \\
6 \\
19\end{array}$ & $\begin{array}{r}11 \\
9 \\
10 \\
14\end{array}$ & $\begin{array}{l}19 \\
21 \\
18\end{array}$ & $\begin{array}{l}21 \\
13 \\
20 \\
40\end{array}$ & $\begin{array}{l}27 \\
26 \\
29 \\
25\end{array}$ \\
\hline HBO haven en vervoer & 7 & 8 & 0 & . & 14 \\
\hline HBO medisch laboratorium & 7 & 1 & 3 & 15 & 13 \\
\hline $\begin{array}{l}\text { HBO technische bedrijfskunde } \\
\text { HTO Opleiding bedrijfskader } \\
\text { HTO Logistiek (management) } \\
\text { HTO Technische bedrijfskunde } \\
\text { HEO/HTO Logistiek en Economie }\end{array}$ & $\begin{array}{r}23 \\
21 \\
. \\
.\end{array}$ & $\begin{array}{r}25 \\
26 \\
. \\
.\end{array}$ & $\begin{array}{l}29 \\
18 \\
26 \\
43\end{array}$ & $\begin{array}{l}32 \\
47\end{array}$ & $\begin{array}{l}31 \\
42\end{array}$ \\
\hline $\begin{array}{l}\text { Totaal HBO technisch (excl. deeltijd) } \\
\text { Totaal HBO technisch (incl. deeltijd) } \\
\text { Totaal HBO }\end{array}$ & $\begin{array}{l}11 \\
11 \\
17\end{array}$ & $\begin{array}{l}10 \\
10 \\
15\end{array}$ & $\begin{array}{l}17 \\
16 \\
17\end{array}$ & $\begin{array}{l}18 \\
18 \\
19\end{array}$ & $\begin{array}{l}19 \\
19 \\
21\end{array}$ \\
\hline
\end{tabular}

Bron: ROA (HBO-Monitor)

Als vijfde en laatste indicator voor mogelijke aansluitingsproblemen wordt gekeken naar het dienstverband van de schoolverlaters. Het percentage HBO'ers dat geen vaste aanstelling heeft neemt sterk toe in de periode 1991-1995, zoals blijkt uit tabel 2.9. Hoewel het werkloosheidspercentage in 1995 daalt ten opzichte van 1994 blijft het percentage van de afgestudeerde HBO'ers dat een tijdelijke aanstelling heeft 


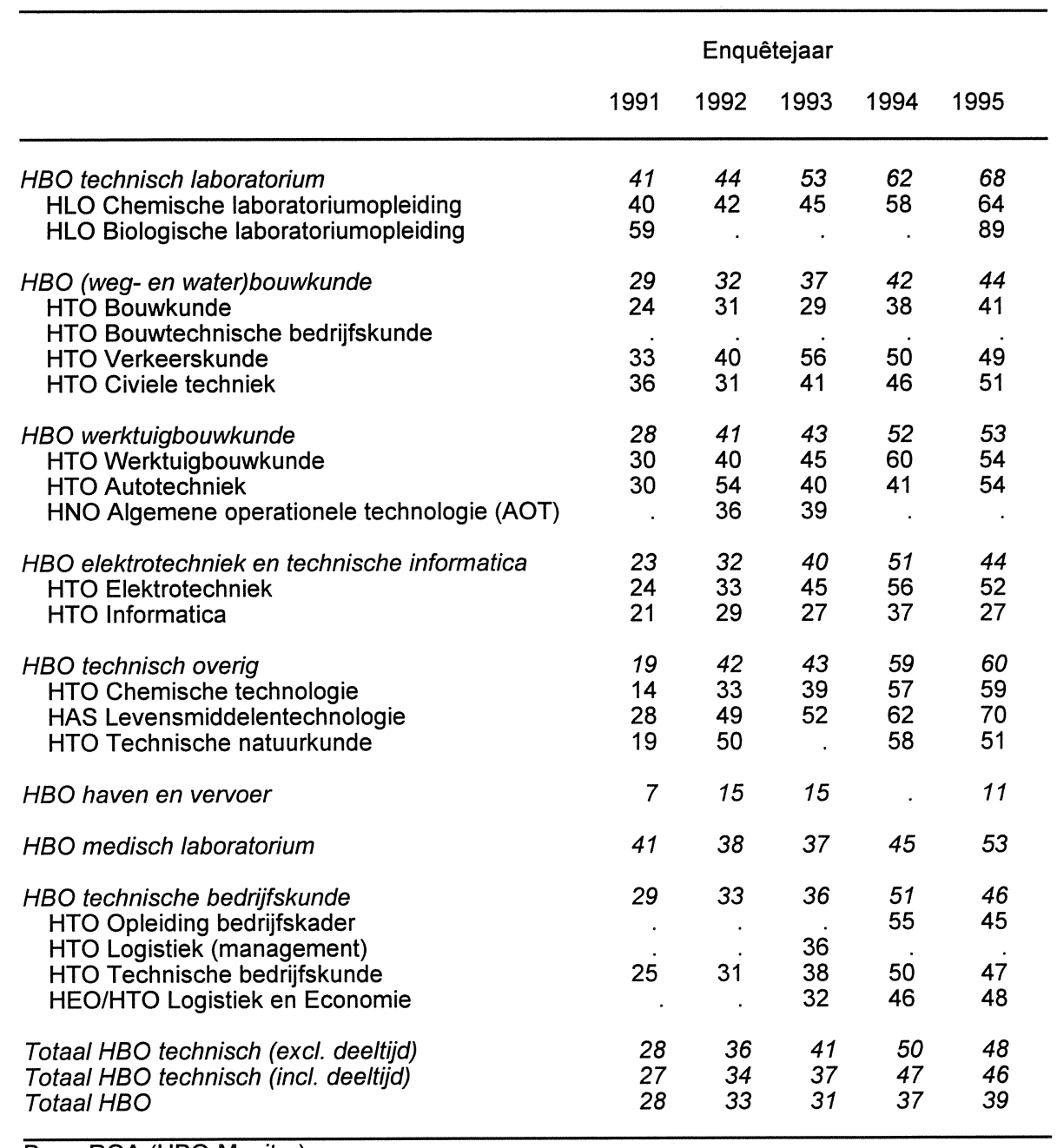

Bron: ROA (HBO-Monitor)

stijgen. Opvallend is dat bij de meeste technische opleidingstypes het percentage met een tijdelijke aanstelling in 1995 ver boven het gemiddelde voor alle HBOopleidingen ligt. Bij de opleidingstypen HBO technisch laboratorium en HBO medisch laboratorium was het percentage met een tijdelijk aanstelling ook in 1991 al erg hoog. Voor de meeste andere technische opleidingstypes geldt dat echter niet. Bij HBO (weg- en water)bouwkunde heeft in 1991 nog geen $30 \%$ geen vaste aanstelling, in 1995 is dat percentage opgelopen tot bijna $45 \%$. Voor schoolverlaters uit de richting HTO civiele techniek is dat zelfs meer dan $50 \%$. Bij het opleidingstype HBO elektrotechniek en technische informatica heeft meer dan $50 \%$ een tijdelijk contract. Wederom is de situatie voor afgestudeerden van de opleiding HTO infor- 
matica veel gunstiger dan de voor afgestudeerden van de opleiding HTO elektrotechniek.

\section{Conclusies}

Op grond van de cijfers over de arbeidsmarktpositie van afgestudeerden van de technische opleidingen op HBO-niveau kan geconcludeerd worden dat de arbeidsmarktpositie van technisch opgeleiden sterk kan fluctueren van jaar tot jaar. Dat geldt ook voor opleidingen waarbij sprake was van knelpunten in de personeelsvoorziening over de periode 1990-1994. De conjuncturele situatie kan dus kennelijk ook de positie van een opleidingsrichting met een op langere termijn gezien gunstige vraag-aanbod-verhouding tijdelijk verslechteren. Verder zijn er aanwijzingen dat de kansen op knelpunten in de personeelsvoorziening bij een aantal opleidingstypen enigszins uiteenlopen tussen onderliggende opleidingen. Zo lijkt bij HBO (weg- en water)bouwkunde de arbeidsmarktpositie van afgestudeerden van de opleidingen HTO civiele techniek en HTO bouwkunde over het algemeen wat beter te zijn dan de arbeidsmarktpositie van afgestudeerden van de opleiding HTO verkeerskunde. De knelpunten in de personeelsvoorziening zullen bij laatstgenoemde opleiding daarom ook minder groot zijn geweest. Verder geldt dat de kleine kans op knelpunten in de personeelsvoorziening bij HBO elektrotechniek en technische informatica vooral betrekking heeft op de opleiding HTO elektrotechniek. Bij HTO informatica is waarschijnlijk wel sprake geweest van knelpunten in de personeelsvoorziening. Ten slotte lijkt bij HBO werktuigbouwkunde de arbeidsmarktpositie van afgestudeerden van de opleidingen HTO autotechniek op meerdere punten slechter te zijn dan die van afgestudeerden van de opleiding HTO werktuigbouwkunde. Bij laatst genoemde opleiding zullen dus meer knelpunten bij de personeelsvoorziening zijn geweest.

\subsection{Verwachte arbeidsmarktontwikkelingen tot 2000}

In de periode 1990-1994 was, zoals bleek uit tabel 2.4, lang niet bij alle technische opleidingstypen sprake van knelpunten in de personeelsvoorziening. Vanaf 1992 verslechtert bovendien de arbeidsmarktpositie van veel opleidingstypes aanzienlijk. Uit recente cijfers van de HBO-Monitor blijkt in 1995 bij de meeste technische opleidingstypes een verbetering op te treden in de arbeidsmarktpositie van recent afgestudeerden. In deze paragraaf zal worden bekeken of deze verbetering zich de komende jaren zal voorzetten. De gegevens in deze paragraaf zijn afkomstig uit $D e$ arbeidsmarkt naar opleiding en beroep tot 2000 (ROA, 1995 a,b).

Uit tabel 2.10 blijkt dat de verwachte uitbreidingsvraag voor de periode 1995-2000 voor alle technische opleidingstypes veel hoger is dan in de voorgaande periode. Met name de uitbreidingsvraag voor het opleidingstype $\mathrm{HBO}$ elektrotechniek en technische informatica stijgt aanmerkelijk. Deze hoge vraag wordt vooral veroorzaakt door de hoge groei in de werkgelegenheid voor programmeurs en systeem- 
analisten. Hoewel het hier gaat om prognoses tot 2000 zijn er het afgelopen jaar reeds duidelijke signalen in de media geweest dat zich hier ernstige knelpunten in de personeelsvoorziening voordoen. Als gevolg van de demografische ontwikkelingen zal de vervangingsvraag voor de meeste opleidingstypes de komende periode naar verwachting iets hoger ligger dan in de periode 1990-1994. Deze wordt weergegeven in tabel 2.11. Alleen bij HBO (weg- en water)bouwkunde en bij HBO technische bedrijfskunde is de vervangingsvraag voor de komende periode naar verhouding wat lager dan in de afgelopen periode. $\mathrm{Bij} \mathrm{HBO}$ (weg- en water)bouwkunde is het aandeel van jongeren de afgelopen jaren sterk gestegen. Absoluut gezien zal de vervangingsvraag echter ook hier verder stijgen. De verwachte vervangingsvraag is hoog voor de opleidingtypes $\mathrm{HBO}$ technisch laboratorium, HBO werktuigbouwkunde en $\mathrm{HBO}$ haven en vervoer. Voor $\mathrm{HBO}$ elektrotechniek en technische informatica en HBO medisch laboratorium is de vervangingsvraag laag. $\mathrm{Bij}$ technische bedrijfskunde is de verwachte vervangingsvraag zelfs erg laag.

Tabel 2.10

Verwachte uitbreidingsvraag 1995-2000

\begin{tabular}{lrrrr}
\hline Opleidingstype & Aantal & $\begin{array}{c}\text { Totaal } \\
\%\end{array}$ & $\begin{array}{c}\text { Gemiddeld Typering } \\
\text { jaarlijks \% }\end{array}$ \\
\hline HBO technisch laboratorium & 6.000 & 22 & 4,0 & hoog \\
HBO (weg- en water)bouwkunde & 5.300 & 15 & 2,7 & hoog \\
HBO werktuigbouwkunde & 5.100 & 17 & 3,2 & hoog \\
HBO elektrotechniek en technische informatica & 11.200 & 27 & 4,8 & erg hoog \\
HBO technisch overig & 2.700 & 15 & 2,9 & hoog \\
HBO haven en vervoer & 4.300 & 15 & 2,9 & hoog \\
HBO medisch laboratorium & 3.400 & 16 & 2,9 & hoog \\
HBO technische bedrijfskunde & 2.800 & 22 & 4,0 & hoog \\
\hline
\end{tabular}

Bron: ROA

Tabel 2.11

Verwachte vervangingsvraag $1995-2000$

\begin{tabular}{lcccl}
\hline Opleidingstype & Aantal & $\begin{array}{c}\text { Totaal } \\
\%\end{array}$ & $\begin{array}{c}\text { Gemiddeld Typering } \\
\text { jaarlijks \% }\end{array}$ \\
\hline HBO technisch laboratorium & 4.600 & 17 & 3,1 & hoog \\
HBO (weg- en water)bouwkunde & 5.700 & 16 & 3,0 & gemiddeld \\
HBO werktuigbouwkunde & 5.100 & 17 & 3,2 & hoog \\
HBO elektrotechniek en technische informatica & 4.600 & 11 & 2,1 & laag \\
HBO technisch overig & 2.700 & 15 & 2,9 & hoog \\
HBO haven en vervoer & 5.400 & 19 & 3,5 & hoog \\
HBO medisch laboratorium & 2.300 & 11 & 2,0 & $\begin{array}{l}\text { laag } \\
\text { erg laag }\end{array}$ \\
HBO technische bedrijfskunde & 1.200 & 9 & 1,8 & \\
\hline
\end{tabular}

Bron: ROA

Tabel 2.12 geeft de verwachte arbeidsmarktinstroom van schoolverlaters voor de komende periode. Over het algemeen is de arbeidsmarktinstroom van schoolverla- 
ters aan het dalen. De arbeidsmarktinstroom van afgestudeerden uit de richting HBO technische bedrijfskunde is de komende periode echter hoger dan in de jaren 19901994. Bij de opleidingstype HBO werktuigbouwkunde en $\mathrm{HBO}$ elektrotechniek en technische informatica blijft de arbeidsmarktinstroom de komende jaren eveneens hoog. De arbeidsmarktinstroom van afgestudeerden uit de richtingen $\mathrm{HBO}$ (weg- en water)bouwkunde, $\mathrm{HBO}$ haven en vervoer en $\mathrm{HBO}$ medisch laboratorium zal de komende jaren daarentegen gaan dalen.

Tabel 2.12

Verwachte arbeidsmarktinstroom, 1995-2000

\begin{tabular}{|c|c|c|c|c|}
\hline Opleidingstype & Aantal & Totaal & $\begin{array}{l}\text { Gemiddeld } \\
\%\end{array}$ & $\begin{array}{l}\text { Typering } \\
\text { jaarlijks \% }\end{array}$ \\
\hline $\begin{array}{l}\text { HBO technisch laboratorium } \\
\text { HBO (weg- en water)bouwkunde } \\
\text { HBO werktuigbouwkunde } \\
\text { HBO elektrotechniek en technische informatica } \\
\text { HBO technisch overig } \\
\text { HBO haven en vervoer } \\
\text { HBO medisch laboratorium } \\
\text { HBO technische bedrijfskunde }\end{array}$ & $\begin{array}{r}4.700 \\
4.300 \\
9.800 \\
13.700 \\
3.800 \\
1.300 \\
2.600 \\
6.500\end{array}$ & $\begin{array}{r}17 \\
12 \\
32 \\
32 \\
21 \\
5 \\
12 \\
51\end{array}$ & $\begin{array}{l}3,2 \\
2,2 \\
5,8 \\
5,8 \\
4,0 \\
0,9 \\
2,3 \\
8,6\end{array}$ & $\begin{array}{l}\text { gemiddeld } \\
\text { laag } \\
\text { hoog } \\
\text { hoog } \\
\text { gemiddeld } \\
\text { laag } \\
\text { laag } \\
\text { erg hoog }\end{array}$ \\
\hline
\end{tabular}

Bron: ROA

Tabel 2.13

Verwachte toekomstige knelpunten in de personeelsvoorziening, 1995-2000

\begin{tabular}{lll}
\hline Opleidingstype & ITKP & $\begin{array}{c}\text { Typering } \\
\text { knelpunten }\end{array}$ \\
& & \\
\hline HBO technisch laboratorium & & groot \\
HBO (weg- en water)bouwkunde & 0,85 & groot \\
HBO werktuigbouwkunde & 0,83 & redelijk groot \\
HBO elektrotechniek en technische informatica & 0,98 & groot \\
HBO technisch overig & 0,94 & groot \\
HBO haven en vervoer & 0,88 & groot \\
HBO medisch laboratorium & 0,79 & groot \\
HBO technische bedrifskunde & 0,91 & zeer klein \\
\hline
\end{tabular}

\section{Bron: ROA}

Tenslotte geeft tabel 2.13 de verwachte toekomstige knelpunten in de personeelsvoorziening per opleidingstype. Deze verwachte knelpunten zijn opnieuw gebaseerd op de vraag-aanbod-verhoudingen voor de komende periode. Als de indicator lager is dan 1 worden knelpunten voorzien, terwijl een indicator boven 1 aangeeft dat het aanbod groter is dan de vraag. In tegenstelling tot de jaren 1990-1994 wordt nu voor bijna alle technische opleidingstypes op HBO niveau knelpunten in de personeelsvoorziening verwacht. Uitzondering is het opleidingstype $\mathrm{HBO}$ technische bedrijfskunde. Bij dit opleidingstype is de kans op knelpunten nog steeds zeer klein. Hoewel de uitbreidingsvraag voor dit opleidingstype wel hoog is, is de vervangingsvraag zo 
laag en de arbeidsmarktinstroom zo hoog dat voor dit opleidingstype toch geen knelpunten worden verwacht. Ook de komende jaren worden de grootste knelpunten verwacht bij HBO haven en vervoer en bij HBO (weg- en water)bouwkunde. Deze knelpunten worden veroorzaakt door de relatief lage instroom van schoolverlaters uit deze richtingen. $\mathrm{Bij} \mathrm{HBO}$ werktuigbouwkunde en $\mathrm{HBO}$ elektrotechniek en technische informatica is de kans op knelpunten iets kleiner dan bij de andere technische richtingen omdat de arbeidsmarktinstroom uit deze richtingen vrij hoog is. 


\section{De werkgelegenheid voor HBO-technici naar bedrijfssector}

\subsection{Inleiding}

In hoofstuk 2 bleek dat de komende jaren veel knelpunten worden verwacht bij de rekrutering van HBO-technici. In het begin van de jaren ' 90 was er slechts sprake van knelpunten bij enkele richtingen, terwijl in de komende periode problemen worden voorzien voor alle technische richtingen op HBO-niveau, met uitzondering van HBO technische bedrijfskunde. In dit hoofdstuk zal worden bekeken welke bedrijfssectoren naar verwachting de meeste knelpunten zullen ondervinden bij het aantrekken van technisch geschoold personeel. Verder zal worden ingegaan op de conjunctuurgevoeligheid van de werkgelegenheid voor HBO-technici en op de mogelijkheden voor HBO technici om uit te wijken naar andere bedrijfstakken.

\subsection{De werkgelegenheid naar bedrijfssector}

Tabel 3.1 geeft de belangrijkste bedrijfssectoren voor technisch opgeleiden op HBOniveau. De gegevens uit deze tabel zijn gebaseerd op de Enquête Beroepsbevol$\mathrm{king}^{4}$. De werkgelegenheid blijkt voor de meeste opleidingen redelijk gespreid te zijn over de verschillende bedrijfssectoren. Uitzondering is het opleidingstype HBO medisch laboratorium. Bij dit opleidingstype is de werkgelegenheid geconcentreerd in de kwartaire diensten. De overige commerciële dienstverlening is voor veel technische opleidingstypes een belangrijke sector. Daarnaast werkt ook een aanzienlijk deel van de HBO'ers in de handel. Voor mensen die een opleiding in de richting $\mathrm{HBO}$ technische bedrijfskunde hebben afgerond is de handel zelfs een van de belangrijkste bedrijfssectoren. Andere belangrijke bedrijfssectoren zijn onder andere: de metaal en elektrotechniek voor $\mathrm{HBO}$ werktuigbouwkunde en $\mathrm{HBO}$ elektrotechniek en technische informatica, de chemie voor HBO technisch laboratorium, de bouw voor HBO (weg- en water)bouwkunde en de sector transport, opslag en communicatie voor HBO haven en vervoer. Verder werkt ook nog een deel van de technisch opgeleiden bij de overheid. Met name voor mensen met een opleiding in de richting $\mathrm{HBO}$ technisch laboratorium en HBO (weg- en water)bouwkunde is de overheid een belangrijke werkgever.

4. Voor een beschrijving van de gehanteerde methodiek bij het bepalen van de trends zie Borghans e.a., 1995. 
Tabel 3.1

Belangrijkste bedrijfssectoren voor HBO-technici, gemiddelde 1994-1995

\begin{tabular}{|c|c|c|}
\hline Opleidingstype & $\%$ & $\begin{array}{l}\text { Trend } \\
\text { 1994-'95 }\end{array}$ \\
\hline \multicolumn{3}{|l|}{ HBO technisch laboratorium } \\
\hline Overheid & 22 & sterk dalend \\
\hline Chemie & 22 & stijgend \\
\hline Kwartaire diensten & 19 & dalend \\
\hline Overige commerciële dienstverlening & 12 & sterk stijgend \\
\hline Andere bedrijfssectoren & 26 & - \\
\hline \multicolumn{3}{|l|}{ HBO (weg- en water)bouwkunde } \\
\hline Overige commerciële dienstverlening & 32 & sterk dalend \\
\hline Bouw & 26 & constant \\
\hline Overheid & 26 & sterk stijgend \\
\hline Andere bedrijfssectoren & 17 & - \\
\hline \multicolumn{3}{|l|}{ HBO werktuigbouwkunde } \\
\hline Metaal en elektrotechniek & 32 & sterk stijgend \\
\hline Overige commerciële dienstverlening & 22 & dalend \\
\hline Handel & 12 & sterk stijgend \\
\hline Overheid & 9 & sterk dalend \\
\hline Andere bedrijfssectoren & 25 & - \\
\hline \multicolumn{3}{|c|}{ HBO elektrotechniek en technische informatica } \\
\hline Overige commerciële dienstverlening & 24 & stijgend \\
\hline Metaal en elektrotechniek & 24 & constant \\
\hline Handel & 13 & sterk stijgend \\
\hline Overheid & 9 & sterk dalend \\
\hline Transport, opslag en communicatie & 6 & sterk dalend \\
\hline Bouw & 6 & sterk stijgend \\
\hline Andere bedrijfssectoren & 18 & - \\
\hline \multicolumn{3}{|l|}{ HBO haven en vervoer } \\
\hline Transport, opslag en communicatie & 35 & sterk stijgend \\
\hline Handel & 11 & dalend \\
\hline Energie & 10 & stijgend \\
\hline Overige commerciële dienstverlening & 10 & constant \\
\hline Overheid & 9 & sterk dalend \\
\hline Andere bedrijfssectoren & 27 & - \\
\hline \multicolumn{3}{|l|}{ HBO medisch laboratorium } \\
\hline Kwartaire diensten & 75 & constant \\
\hline Andere bedrijfssectoren & 25 & - \\
\hline \multicolumn{3}{|l|}{ HBO technische bedrijfskunde } \\
\hline Handel & 18 & sterk dalend \\
\hline $\begin{array}{l}\text { Overige commerciële dienstverlening } \\
\text { Andere bedrijfssectoren }\end{array}$ & $\begin{array}{l}17 \\
65\end{array}$ & $\begin{array}{l}\text { sterk stijgend } \\
\text { - }\end{array}$ \\
\hline
\end{tabular}

Bron: CBS/ROA

Uit tabel 3.2 blijkt dat met uitzondering van de overheidssector de werkgelegenheid zal gaan groeien in vrijwel alle sectoren die voor technisch opgeleiden van belang zijn. Bij de overheid wordt een werkgelegenheidsdaling van $0,9 \%$ per jaar verwacht. Vooral in de chemie, de handel en de overige commerciële dienstverlening is de verwachte werkgelegenheidsgroei aanzienlijk. Dit roept de vraag op of deze snel 
groeiende sectoren niet te maken gaan krijgen met een tekort aan technisch opgeleid personeel.

Tabel 3.2

Verwachte werkgelegenheidsontwikkeling per bedrijfssector, 1995-2000.

\begin{tabular}{|c|c|c|c|c|}
\hline Bedrijfssector & Aantal & $\begin{array}{c}\text { Totaal } \\
\%\end{array}$ & $\begin{array}{l}\text { Gemiddeld } \\
\text { jaarlijks \% }\end{array}$ & Typering \\
\hline $\begin{array}{l}\text { Landbouw en visserij } \\
\text { Voedings- en genotmiddelenindustrie } \\
\text { Overige industrie } \\
\text { Chemie } \\
\text { Metaal en elektrotechniek } \\
\text { Energie } \\
\text { Bouw } \\
\text { Handel } \\
\text { Transport, opslag en communicatie } \\
\text { Overige commerciële dienstverlening } \\
\text { Bank- en verzekeringswezen } \\
\text { Kwartaire diensten } \\
\text { Overheid }\end{array}$ & $\begin{array}{r}-38.300 \\
-4.900 \\
-3.000 \\
11.400 \\
9.000 \\
1.300 \\
13.000 \\
92.200 \\
12.800 \\
102.400 \\
-5.600 \\
87.700 \\
-35.100\end{array}$ & $\begin{array}{r}-14 \\
-3 \\
-1 \\
10 \\
2 \\
2 \\
3 \\
10 \\
4 \\
10 \\
-3 \\
10 \\
-5\end{array}$ & $\begin{array}{r}-2,9 \\
-0,6 \\
-0,3 \\
1,8 \\
0,5 \\
0,4 \\
0,6 \\
1,8 \\
0,7 \\
1,9 \\
-0,6 \\
2,0 \\
-0,9\end{array}$ & $\begin{array}{l}\text { erg laag } \\
\text { laag } \\
\text { gemiddeld } \\
\text { hoog } \\
\text { gemiddeld } \\
\text { gemiddeld } \\
\text { gemiddeld } \\
\text { hoog } \\
\text { gemiddeld } \\
\text { hoog } \\
\text { laag } \\
\text { hoog } \\
\text { laag }\end{array}$ \\
\hline
\end{tabular}

Bron: CPB/ROA

Om een beeld te krijgen van de gevolgen van de tekorten zal eerst worden ingegaan op de componenten van de verwachte werkgelegenheidsontwikkeling voor technisch opgeleiden op HBO-niveau. Tabel 3.3 geeft de verwachte werkgelegenheidsgroei voor technisch opgeleiden uitgesplitst naar de verschillende onderliggende vraagcomponenten. Het bedrijfssectoreffect geeft de verwachte vraagtoename als gevolg van de groeiende werkgelegenheid per bedrijfssector bij een gelijkblijvende opleidingsstructuur per bedrijfssector. Het beroepseffect geeft de vraagtoename als gevolg van een groei van het aandeel van beroepen waarin HBO-technici werkzaam zijn binnen de betreffende bedrijfssectoren. Het opleidingseffect geeft vervolgens de extra vraag als gevolg van upgrading van de werkgelegenheid in verschillende beroepen. Als er sprake is van upgrading dan neemt het belang van HBO'ers in een beroep toe ten opzichte van de lagere opleidingsniveaus ${ }^{5}$. Het sectoreffect, het beroepseffect en het opleidingseffect geven tezamen de uitbreidingsvraag voor een opleiding. De uitbreidingsvraag is de verwachte vraag bij onveranderde vraag-aanbodverhoudingen op de arbeidsmarkt. De passieve substitutievraag is de extra vraag voor een opleiding die ontstaat doordat er tekorten zijn bij andere opleidingen. Met deze substitutievraag wordt, zoals in hoofdstuk 2 al werd opgemerkt, rekening gehouden bij het bepalen van de verwachte knelpunten in de personeelsvoorziening. Het actieve substitutie-effect geeft tenslotte de krimp in de werkgelegenheid

5. Overigens kan als gevolg van upgrading ook het belang van het $\mathrm{HBO}$ afnemen ten gunstige van het WO. 
die ontstaat doordat het aanbod tekort schiet ${ }^{6}$. Werkgevers moeten om in de vraag naar technici te voldoen mensen met een andere opleidingsachtergrond rekruteren. De actieve substitutie geeft dus een indicatie van de omvang van de tekorten per opleidingstype. Hoe ernstig deze tekorten zijn hangt uiteraard samen met de mate waarin werkgevers mensen met een andere opleidingsachtergrond kunnen substitueren voor technisch opgeleiden op HBO-niveau. Het bedrijfssectoreffect is het grootst voor HBO technisch laboratorium en HBO medisch laboratorium. Dit hoge bedrijfssectoreffect bij beide opleidingstypes is terug te voeren op de sterk groeiende werkgelegenheid in de chemie, de overige commerciële dienstverlening en de kwartaire diensten.

Het beroepseffect is erg hoog voor het opleidingstype HBO elektrotechniek en informatica. In hoofdstuk 2 werd al opgemerkt dat dit wordt veroorzaakt door de sterke groei van de werkgelegenheid voor systeemanalisten en programmeurs binnen verschillende bedrijfssectoren. Het opleidingseffect is vooral erg hoog voor de opleiding HBO haven en vervoer. Bij het werk dat door deze opleiding relevant is, wordt kennelijk meer en meer een HBO opleiding vereist.

Uit de omvang van de actieve substitutie in de tabel blijkt dat bij een aantal opleidingen in het geheel niet aan de uitbreidingsvraag en passieve substitutievraag kan worden voldaan. Dat geldt voor HBO technisch laboratorium en HBO (weg- en water)bouwkunde. Bij de overige opleidingen, met uitzondering van $\mathrm{HBO}$ technische bedrijfskunde, kan de vraag slechts gedeeltelijk worden vervuld. Bij HBO technische bedrijfskunde doen zich geen problemen voor.

Tabel 3.3

Verwachte werkgelegenheidsgroei voor HBO-technici uitgesplitst naar verschillende vraagcomponenten, 1995-2000

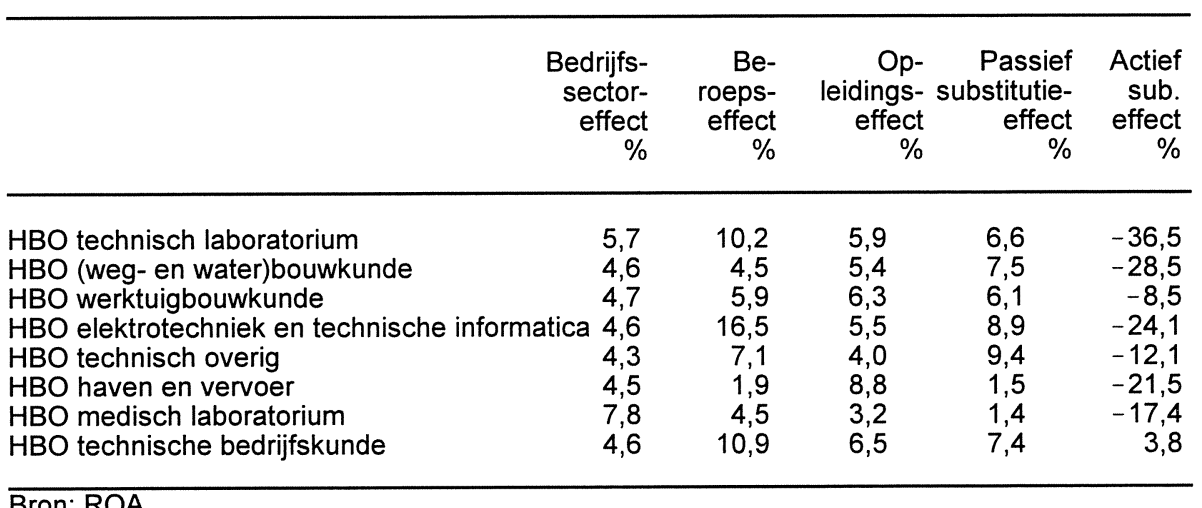

Bron: ROA

6. Zie De Grip, Borghans en Smits (1996). 
In tabel 3.4 wordt een overzicht gegeven van het aandeel van HBO-technici in de werkgelegenheid per bedrijfssector. In de sectoren landbouw en visserij, voedingsen genotmiddelenindustrie, de overige industrie en het bank- en verzekeringswezen werken te weinig technisch opgeleiden op HBO-niveau om uitspraken te kunnen doen over verwachte tekorten.

Tabel 3.4

Aandeel HBO-technici in de totale werkgelegenheid per bedrijfssector, gemiddeld 1994-1995

\begin{tabular}{lll}
\hline Bedrijfssector & $\%$ & Trend \\
& $1994-95$
\end{tabular}

Landbouw en visserij

Voedings- en genotmiddelenindustrie

Overige industrie

Chemie

HBO technisch laboratorium

constant

Metaal en elektrotechniek

$\mathrm{HBO}$ werktuigbouwkunde

$\mathrm{HBO}$ elektrotechniek en technische informatica

$2 \quad$ sterk stijgend

Energie

HBO haven en vervoer

stijgend

Bouw

HBO (weg-en water)bouwkunde

$\mathrm{HBO}$ elektrotechniek en technische informatica

$2 \quad$ stijgend

Handel

HBO elektrotechniek en technische informatica

$\mathrm{HBO}$ werktuigbouwkunde

$\mathrm{HBO}$ haven en vervoer

HBO technische bedrijfskunde

constant

Transport, opslag en communicatie

HBO haven en vervoer

HBO elektrotechniek en technische informatica

3 stijgend

1 sterk dalend

Overige commerciële dienstverlening

HBO (weg-en water)bouwkunde

HBO elektrotechniek en technische informatica

$\mathrm{HBO}$ werktuigbouwkunde

HBO technisch laboratorium

HBO haven en vervoer

$\mathrm{HBO}$ technische bedrijfskunde

dalend
constant
constant
sterk stijgend
constant
sterk stijgend


Tabel 3.4 (vervolg)

Aandeel HBO-technici in de totale werkgelegenheid per bedrijfssector, gemiddeld 1994-1995

\begin{tabular}{lll}
\hline Bedrijfssector & $\%$ & $\begin{array}{l}\text { Trend } \\
1994-' 95\end{array}$ \\
\hline Bank- en verzekeringswezen & - & - \\
Kwartaire diensten & & \\
HBO medisch laboratorium & 2 & $\begin{array}{l}\text { dalend } \\
\text { dalend }\end{array}$ \\
HBO technisch laboratorium & 1 & \\
Overheid & & \\
HBO (weg- en water)bouwkunde & 1 & $\begin{array}{l}\text { stijgend } \\
\text { sterk dalend } \\
\text { sterk dalend } \\
\text { sterk dalend } \\
\text { dalend }\end{array}$ \\
HBO technisch laboratorium & 1 & 0 \\
HBO werktutechniek en technische informatica & 0 & 0
\end{tabular}

Bron: CBS/ROA

Ongeveer $4 \%$ van de werkenden in de chemie heeft een opleiding in de richting HBO technisch laboratorium gevolgd. Hoewel dit aandeel in 1994 en 1995 constant blijft, valt door de snel groeiende werkgelegenheid in deze sector toch te verwachten dat zich knelpunten gaan voordoen als gevolg van tekorten aan personen met een opleiding in de richting HBO technisch laboratorium. Voor de metaal- en elektrotechnische industrie zijn de opleidingstypes $\mathrm{HBO}$ werktuigbouwkunde en HBO elektrotechniek en informatica van belang. Gezien de verwachte groei van deze bedrijfssector is er een grote kans dat in deze sector knelpunten zullen ontstaan door tekorten aan personen met een opleiding HBO werktuigbouwkunde en HBO elektrotechniek en technische informatica. In de energiesector kan hinder worden ondervonden door tekorten aan mensen die een opleiding in de richting $\mathrm{HBO}$ haven en vervoer hebben afgerond. Het belang van dit opleidingstype voor deze sector neemt de laatste jaren toe. In de bouw kunnen knelpunten ontstaan door tekorten aan technisch opgeleiden in de richtingen $\mathrm{HBO}$ werktuigbouwkunde en $\mathrm{HBO}$ elektrotechniek en technische informatica. Niet alleen groeit de werkgelegenheid in de bouw, ook stijgt het aandeel van de werkenden met een opleiding in een van beide richtingen. In de handel kunnen eveneens knelpunten onstaan door tekorten aan technisch opgeleiden. De werkgelegenheid in deze sector groei snel. Tegelijkertijd worden de opleidingstypes $\mathrm{HBO}$ elektrotechniek en technische informatica, HBO werktuigbouwkunde en $\mathrm{HBO}$ haven en vervoer steeds belangrijker voor deze sector. In de sector transport, opslag en communicatie kunnen problemen onstaan door tekorten aan personen die een opleiding in de richting $\mathrm{HBO}$ haven en veroer hebben voltooid. Het is minder waarschijnlijk dat zich tekorten voordoen aan personen die een opleiding in de richting HBO elektrotechniek en technische informatica hebben gevolgd, omdat het aandeel van werkenden met een dergelijke opleidingsachtergrond sterk daalt. 
In de overige commerciële dienstverlening kunnen tekorten onstaan aan technisch opgeleiden in de richtingen $\mathrm{HBO}$ (weg- en water)bouwkunde, $\mathrm{HBO}$ elektrotechniek en technische informatica, HBO werktuigbouwkunde, HBO technisch laboratorium en HBO haven en vervoer. Weliswaar daalt het aandeel van personen met een opleiding in de richting HBO (weg-en water)bouwkunde, maar dat kan ook een rechtstreeks gevolg zijn van reeds bestaande tekorten bij dit opleidingstype. Bij dit opleidingstype doen zich immers al enkele jaren tekorten voor. In de kwartaire diensten kunnen knelpunten onstaan als gevolg van tekorten aan mensen met een opleiding in de richting HBO technisch laboratorium of HBO medisch laboratorium. Weliswaar neemt het aandeel van werkenden met deze opleidingsachtergrond af, maar de groei van de totale werkgelegenheid in de sector is zo hoog dat tekorten toch niet uitgesloten kunnen worden. Bij de overheid daalt het aandeel van HBO technisch opgeleiden. Omdat verder de werkgelegenheid bij de overheid de komende jaren naar verwachting zal dalen, zal de overheid waarschijnlijk alleen knelpunten ondervinden door tekorten aan HBO (weg- en water)bouwkundigen.

\subsection{Conjuctuurgevoeligheid van de werkgelegenheid}

In hoofdstuk 2 werd duidelijk dat de arbeidsmarktpositie van afgestudeerden van technische opleidingen sterk kan verschillen van jaar tot jaar. In deze paragraaf zal worden bekeken of de werkgelegenheid voor technisch opgeleiden conjunctuurgevoeliger is dan de werkgelegenheid van afgestudeerden uit andere HBO-richtingen. Tabel 3.6 laat zien dat de werkgelegenheid in veel bedrijfssectoren die van belang zijn voor HBO technici erg conjunctuurgevoelig is. Dat geldt bijvoorbeeld voor de de chemie, de metaal en elektrotechniek en de bouw. Daarentegen is de conjunctuurgevoeligheid van de werkgelegenheid in de overige commerciele dienstverlening en de kwartaire diensten, twee bedrijfssectoren waar toch een flink deel van de werkgelegenheid voor HBO-technisch opgeleiden is geconcentreerd, gering. Daardoor is de conjunctuurgevoeligheid voor de meeste technische opleidingen op HBO-niveau toch niet bijzonder hoog. Alleen bij het opleidingstype HBO elektrotechniek en technische informatica en $\mathrm{HBO}$ technische bedrijfskunde is sprake van een hoge conjunctuurgevoeligheid van de werkgelegenheid.

De conjunctuurgevoeligheid van de werkgelegenheid voor de opleidingstypes HBO medisch laboratorium en HBO haven en vervoer is zelfs laag. Voor HBO medisch laboratorium is dat niet zo verwonderlijk aangezien driekwart van de werkgelegenheid voor dit opleidingstype is geconcentreerd in de kwartaire diensten, een sector met een lage conjunctuurgevoeligheid.

Als de werkgelegenheid van een opleidingstype sterk afhankelijk is van de conjunctuur dan zal dat vermoedelijk vooral gevolgen hebben voor de arbeidsmarkpositie van recent afgestudeerden. Werknemers die een vaste baan hebben zijn immers vaak moeilijk te ontslaan. Werkgevers zullen dus reageren op een conjuncturele 
neergang door tijdelijke contracten niet te verlengen en door geen nieuwe mensen meer aan te trekken. Op grond van deze overweging valt het te verwachten dat de arbeidsmarktpositie van recent afgestudeerden sterk fluctueert met de conjunctuur.

Tabel 3.6

Conjunctuurgevoeligheid per bedrijfssector

\begin{tabular}{lll}
\hline Bedrijfssector & Conjunctuurgevoeligheid & Typering \\
\hline & & \\
Landbouw en visserij & 0,33 & erg laag \\
Voedings- en genotmiddelenindustrie & 0,68 & gemiddeld \\
Overige industrie & 0,95 & gemiddeld \\
Chemie & 1,03 & hoog \\
Metaal en elektrotechniek & 1,39 & hoog \\
Energie & 1,13 & hoog \\
Bouw & 1,74 & erg hoog \\
Handel & 0,48 & gemiddeld \\
Transport, opslag en communicatie & 0,72 & laag \\
Overige commerciële dienstverlening & 0,46 & gemiddeld \\
Bank- en verzekeringswezen & 0,59 & laag \\
Kwartaire diensten & 0,41 & laag \\
Overheid & 0,47 &
\end{tabular}

Bron: ROA

Tabel 3.7

Conjunctuurgevoeligheid per opleidingsrichting

\begin{tabular}{lll}
\hline Opleidingstype & Conjunctuurgevoeligheid & Typering \\
\hline HBO technisch laboratorium & 0,79 & gemiddeld \\
HBO (weg- en water)bouwkunde & 0,88 & gemiddeld \\
HBO werktuigbouwkunde & 0,86 & gemiddeld \\
HBO elektrotechniek en technische informatica & 1,31 & erg hoog \\
HBO haven en vervoer & 0,62 & laag \\
HBO medisch laboratorium & 0,53 & hoog \\
HBO technische bedrijfskunde & 0,96 &
\end{tabular}

Bron: ROA

Om nu te kijken of de arbeidsmarktpositie van recent afgestudeerden van technische opleidingen op HBO-niveau sterker fluctueert dan de arbeidsmarktpositie van afgestudeerden van andere HBO opleidingen is het verband geschat tussen de werkloosheid per opleidingstype en de gemiddelde werkloosheid (zie appendix 1). Tabel 3.8 geeft de gevonden werkloosheidsparameters. Als deze parameter groter is dan 1 dan ligt de werkloosheid voor het betreffende opleidingstype in de jaren 1991-1995 systematisch hoger dan gemiddeld bij het HBO. Bij een conjunctuurverslechtering neemt de werkloosheid meer dan evenredig toe. De tabel bevestigt in grote lijnen het beeld dat ook al naar voren kwam in hoofdstuk 2. Bij de meeste technische opleidingstypes ligt de werkloosheid systematisch hoger dan de gemiddelde werkloosheid van HBO-afgestudeerden. Uitzonderingen zijn de opleidingstypes HBO (weg- en water)bouwkunde en HBO medisch laboratorium. 
Tabel 3.8

Verband tussen werkloosheid per richting en gemiddelde werkloosheid onder HBO-afgestudeerden (t-waarden tussen haakjes)

\begin{tabular}{lcc}
\hline & Werkloosheidsparameter \\
\hline HBO technisch laboratorium & 1,34 & $(5,60)^{\star \star}$ \\
HBO (weg- en water)bouwkunde & 0,77 & $(6,10)^{\star \star}$ \\
HBO werktuigbouwkunde & 1,45 & $(10,33)^{\star \star}$ \\
HBO elektrotechniek en technische informatica & 1,64 & $(13,62)^{\star \star}$ \\
HBO technisch overig & 1,56 & $(6,20)^{\star \star}$ \\
HBO haven en vervoer & 0,57 & $(4,43)^{\star \star}$ \\
HBO medisch laboratorium & 1,35 & $(7,94)^{\star \star}$ \\
HBO technische bedrijfskunde & & \\
\hline
\end{tabular}

Bron: ROA (HBO-Monitor)

* = significant bij $10 \%$-niveau

$\star \star=$ significant bij $5 \%$-niveau

Vervolgens is het verband geschat tussen de jaarlijkse verandering in de werkloosheid per opleidingstype en de jaarlijkse verandering in de gemiddelde werkloosheid voor het HBO. Deze schatting wordt aangeduid als de fluctuatieparameter. Een fluctuatieparameter groter dan 1 betekent in dit geval dat de werkloosheid voor het betreffende opleidingstype sterker fluctueert dan de gemiddelde werkloosheid voor het HBO (zie appendix 1). Tabel 3.9 laat zien dat de werkloosheid bij een aantal technische opleidingstypes sterker fluctueert dan gemiddeld voor het $\mathrm{HBO}$ het geval is. Met name bij HBO elektrotechniek en technische informatica en HBO technische bedrijfskunde fluctueert de werkloosheid sterk van jaar tot jaar. Dit bevestigt dat met name bij de conjunctuurgevoelige opleidingstypen de werkloosheid sterker reageert op de algehele economische toestand dan bij andere rich-tingen. Kennelijk weet slechts een deel van de schoolverlaters uit deze opleidingstypen uit te wijken naar andere banen als in het eigen domein de vraag achterblijt vanwege conjuncturele oorzaken. Echter ook voor de opleidingstypes HBO (weg- en water)bouwkunde en HBO werktuigbouwkunde - die qua werkgelegenheidsontwikkeling minder conjunctuurgevoelig zijn - fluctueert de werkloosheid aanzienlijk.

Een andere maat voor de fluctuaties in de jaarlijkse werkloosheidscijfers is de variantie van de verandering in de jaarlijkse werkloosheid. Een deel van de geobserveerde jaarlijkse fluctuaties in de werkloosheid kan echter voortkomen uit de steekproefvariantie. Als het aantal waarnemingen in de steekproef voor een bepaald opleidingstype laag is kan het beeld daarom enigzins vertekend zijn. Daarom is per opleidingstype de variantie in de jaarlijkse verandering van de werkloosheid berekend waarbij rekening is gehouden met de steekproefvariantie ${ }^{7}$.

7. In appendix 2 wordt deze correctie besproken. 
Tabel 3.9

Verband tussen jaarlijkse verandering werkloosheid per richting en jaarlijkse verandering gemiddelde werkloosheid onder HBO-afgestudeerden (t-waarden tussen haakjes)

\begin{tabular}{lll}
\hline & \multicolumn{2}{c}{ Fluctuatieparameter } \\
\hline HBO technisch laboratorium & 0,89 & $(1,23)$ \\
HBO (weg- en water)bouwkunde & 1,57 & $(3,30)^{\star *}$ \\
HBO werktuigbouwkunde & 1,80 & $(2,02)^{*}$ \\
HBO elektrotechniek en technische informatica & 2,18 & $(4,39)^{\star *}$ \\
HBO technisch overig & 0,94 & $(0,67)$ \\
HBO haven en vervoer & 0,43 & $(0,53)$ \\
HBO medisch laboratorium & 2,19 & $(3,30)^{\star *}$ \\
HBO technische bedrijfskunde & & \\
\hline
\end{tabular}

Bron: ROA (HBO-Monitor)

* = significant bij $10 \%$-niveau

** $=$ significant bij $5 \%$-niveau

Tabel 3.10 geeft de geschatte variantie van de jaarlijks verandering in de werkloosheid per opleidingstype en de verhouding tussen de variantie per opleidingstype en de variantie in de werkloosheid voor het gehele HBO. Het blijkt dat ook wanneer gecorrigeerd wordt voor de steekproefvariantie, de variantie van de verandering in de werkloosheid erg hoog is voor $\mathrm{HBO}$ technische bedrijfskunde, $\mathrm{HBO}$ werktuigbouwkunde, $\mathrm{HBO}$ elektrotechniek en technische informatica en HBO technisch overig. Alleen bij HBO medisch laboratorium is de variantie lager dan gemiddeld.

Tabel 3.10

Variantie van de jaarlijkse verandering werkloosheid

\begin{tabular}{lcc}
\hline & $\begin{array}{r}\text { Variantie } \\
\text { per opleidingstype } \\
\times 1000\end{array}$ & $\begin{array}{r}\text { Variantie } \\
\text { per opleidingstype } \\
\text { t.o.v. totaal HBO }\end{array}$ \\
\hline HBO technisch laboratorium & 0,8 & 1,14 \\
HBO (weg- en water)bouwkunde & 1,8 & 2,42 \\
HBO werktuigbouwkunde & 3,7 & 5,08 \\
HBO elektrotechniek en technische informatica & 3,6 & 4,97 \\
HBO technisch overig & 4,1 & 5,64 \\
HBO haven en vervoer & 0,5 & 0,69 \\
HBO medisch laboratorium & 3,8 & 5,21 \\
HBO technische bedrijfskunde & &
\end{tabular}

Bron: ROA (HBO-Monitor)

De arbeidsmarktpositie van recent afgestudeerde HBO-technici is dus sterk afhankelijk van de conjunctuur. In hoofstuk 2 bleek eveneens dat HBO-technici die afstudeerden in een jaar waarin de economische situatie ongunstig was, vaak zijn uitgeweken naar beroepen buiten hun eigen vakgebied. In verband met de verwachte toekomstige tekorten aan technisch opgeleiden op HBO-niveau is het interessant om na te gaan of deze mensen die in het verleden zijn uitgeweken toch beschikbaar blijven voor banen in de techniek. Daarbij spelen twee zaken een rol. Ten eerste is 
de arbeidsmarktpositie van technisch opgeleiden buiten de techniek van belang. Als de banen buiten de techniek gunstiger zijn bijvoorbeeld qua salaris, dan zal men weinig moeite doen om alsnog een baan in de techniek te vinden. Ten tweede is het van belang of degenen die zijn uitgeweken nog wel over voldoende technische capaciteiten beschikken om alsnog in de techniek te gaan werken. In het volgende hoofdstuk zal worden ingegaan op verschillen tussen technisch opgeleiden die een baan binnen en buiten de techniek hebben. 



\section{HBO-technici werkzaam buiten de techniek}

\subsection{Inleiding}

Niet iedereen die een technische opleiding heeft gevolgd is ook in een technisch beroep werkzaam. In hoofstuk 2 bleek dat bij een aantal opleidingen een aanzienlijk deel van de recent afgestudeerde technisch opgeleiden aangeeft in een beroep werkzaam te zijn dat qua richting niet aansluit bij de gevolgde opleiding. Technisch opgeleiden kunnen om verschillende redenen uitwijken naar beroepen buiten de techniek. In de eerste plaats kunnen beroepen buiten de techniek aantrekkelijker zijn wat betreft inkomen en werkomstandigheden. Ten tweede is het mogelijk dat sommige afgestudeerden over minder technische vaardigheden beschikken en daarom meer moeite hebben om een baan in de techniek te vinden. Uiteindelijk wijken ze dan uit naar banen buiten de techniek. In het eerste geval is er sprake van positieve selectie naar niet-technische beroepen, in het tweede geval is er sprake van negatieve selectie (zie ook Borghans, De Grip en Smits, 1995). Als de vraag-aanbodverhoudingen op de arbeidsmarkt veranderen zal ook het percentage afgestudeerden dat uitwijkt naar banen buiten de techniek veranderen. Als de vraag naar technisch opgeleiden vanuit niet-technische beroepen toeneemt zullen de lonen voor technisch opgeleiden in niet-technisch beroepen stijgen en zullen meer technici uitwijken naar niet specifiek technische beroepen. Als het aanbod van technisch opgeleiden sterk toeneemt dan zullen technisch opgeleiden meer naar niet-technisch beroepen uitwijken indien de vraag in technische beroepen tekort schiet.

In paragraaf 4.2 zal worden besproken hoe de werkgelegenheid van recent afgestudeerde technici is verdeeld over technische en niet-technische beroepen. Tevens zal worden nagegaan hoe de vraag voor technisch opgeleiden vanuit technische en niet-technische beroepen zich de komende jaren zal ontwikkelen. In paragraaf 4.3 zal vervolgens de arbeidsmarktpositie van technisch opgeleiden werkzaam in technische en niet-technische beroepen worden vergeleken.

\subsection{De verdeling van de werkgelegenheid over technische en niet-technische beroepen}

In hoofstuk 2 werd bekeken in welke mate recent afgestudeerden volgens eigen zeggen in een beroep werkzaam zijn waarvoor een andere opleidingsrichting werd vereist dan waarin ze zijn afgestudeerd. Niet iedereen die zegt dat een andere vakrichting werd vereist is ook in een niet-technisch beroep werkzaam. Het is ook mogelijk dat mensen in een technisch beroep werkzaam zijn, waarvoor eigenlijk een andere afstudeerrichting werd vereist. Verder is het mogelijk dat iemand weliswaar in een niet-technisch beroep werkzaam is, maar dat de werkgever toch iemand met een technische opleidingsachtergrond wilde hebben. In deze paragraaf zal worden bekeken hoeveel technisch opgeleiden werkelijk in een niet-technisch beroep werk- 
zaam zijn. Tabel 4.1 geeft per opleiding het percentage van de recent afgestudeerde HBO'ers dat in een technisch beroep werkzaam is, het percentage dat werkzaam is in een overgangsberoep - dat is een beroep op het grensvlak van de techniek - en het percentage dat werkzaam is in een niet-technisch beroep ${ }^{8}$.

Tabel 4.1

Verdeling van de werkgelegenheid voor technisch opgeleiden op HBO-niveau over technische beroepen, overgangsberoepen en niet-technische beroepen, 1995

\begin{tabular}{|c|c|c|c|}
\hline & $\begin{array}{r}\text { Technisch } \\
\%\end{array}$ & $\begin{array}{r}\text { Overgangs- } \\
\text { beroep } \\
\%\end{array}$ & $\begin{array}{r}\text { Niet-technisch } \\
\%\end{array}$ \\
\hline $\begin{array}{l}\text { HBO technisch laboratorium } \\
\text { HLO Chemisch laboratoriumopleiding } \\
\text { HBO Biologische laboratoriumopleiding }\end{array}$ & $\begin{array}{l}65 \\
67 \\
64\end{array}$ & $\begin{array}{l}5 \\
4 \\
3\end{array}$ & $\begin{array}{l}30 \\
29 \\
33\end{array}$ \\
\hline $\begin{array}{l}\text { HBO (weg-en water)bouwkunde } \\
\text { HTO Bouwkunde } \\
\text { HTO Bouwtechnische bedrijfskunde }\end{array}$ & $\begin{array}{l}74 \\
79\end{array}$ & $\begin{array}{r}9 \\
11\end{array}$ & $\begin{array}{l}17 \\
11\end{array}$ \\
\hline $\begin{array}{l}\text { HTO Verkeerskunde } \\
\text { HTO Civiele techniek }\end{array}$ & $\begin{array}{l}51 \\
87\end{array}$ & $\begin{array}{l}9 \\
2\end{array}$ & $\begin{array}{l}40 \\
10\end{array}$ \\
\hline $\begin{array}{l}\text { HBO werktuigbouwkunde } \\
\text { HTO Werktuigbouwkunde } \\
\text { HTO Autotechniek }\end{array}$ & $\begin{array}{l}58 \\
59 \\
56\end{array}$ & $\begin{array}{l}28 \\
30 \\
14\end{array}$ & $\begin{array}{l}14 \\
10 \\
30\end{array}$ \\
\hline $\begin{array}{l}\text { HBO elektrotechniek en technische informatica } \\
\text { HTO Elektrotechniek } \\
\text { HTO Informatica }\end{array}$ & $\begin{array}{l}35 \\
48 \\
10\end{array}$ & $\begin{array}{l}56 \\
44 \\
81\end{array}$ & $\begin{array}{l}9 \\
8 \\
9\end{array}$ \\
\hline $\begin{array}{l}\text { HBO technisch overig } \\
\text { HTO Chemische technologie } \\
\text { HAS Levensmiddelentechnologie } \\
\text { HTO Technische natuurkunde }\end{array}$ & $\begin{array}{l}52 \\
54 \\
44 \\
55\end{array}$ & $\begin{array}{l}26 \\
19 \\
35 \\
29\end{array}$ & $\begin{array}{l}22 \\
27 \\
20 \\
16\end{array}$ \\
\hline HBO haven en vervoer & 68 & 5 & 27 \\
\hline HBO medisch laboratorium & 22 & 4 & 74 \\
\hline $\begin{array}{l}\text { HBO technische bedrijfskunde } \\
\text { HTO Opleiding bedrijfskader } \\
\text { HTO Technische bedrijfskunde } \\
\text { HEO/HTO Logistiek en Economie }\end{array}$ & $\begin{array}{r}16 \\
2 \\
21 \\
1\end{array}$ & $\begin{array}{l}33 \\
31 \\
38 \\
14\end{array}$ & $\begin{array}{l}51 \\
68 \\
42 \\
85\end{array}$ \\
\hline $\begin{array}{l}\text { Totaal HBO (excl. deeltijd) } \\
\text { Totaal HBO (incl. deeltijd) }\end{array}$ & $\begin{array}{l}45 \\
45\end{array}$ & $\begin{array}{l}31 \\
32\end{array}$ & $\begin{array}{l}24 \\
23\end{array}$ \\
\hline
\end{tabular}

8. Deze indeling is gebaseerd op de Standaard Beroepenclassificatie 19992 (SBC'92) van het CBS. Als meer dan de helft van alle werkenden in een beroep een technische opleidingsachtergrond heeft dan wordt het beroep geclassificeerd als technisch. Als het percentage met een technische opleidingsachtergrond lager is dan $50 \%$ maar de technisch opgeleiden toch nog een van de belangrijkste groepen vormen binnen dat beroep dan wordt het beroep geclassificeerd als een overgangsberoep. In Borghans e.a. (1996) wordt deze indeling uitgebreid besproken. 
Bij de meeste opleidingstypes werkt meer dan de helft van de recent afgestudeerden in een technisch beroep. Uitzondering zijn de opleidingstypes HBO elektrotechniek en informatica, $\mathrm{HBO}$ medisch laboratorium en $\mathrm{HBO}$ technische bedrijfskunde. Bij HBO elektrotechniek wordt het lage percentage dat in een technisch beroep werkzaam is veroorzaakt door de opleiding HTO informatica. Afgestudeerden van deze opleiding zijn veelal in beroepen werkzaam waarin zowel personen met een technische achtergrond als personen met een economische of administratieve opleidingsachtergrond werkzaam zijn. Het betreft voornamelijk informaticaberoepen. Bij HBO medisch laboratorium werken de meeste afgestudeerden in een paramedisch of laboratoriumberoep. Bij HBO technische bedrijfskunde blijkt daarentegen een aanzienlijk deel werkzaam te zijn in economisch administratieve beroepen of in beroepen die gedeeltelijk technisch en gedeeltelijk economisch-administratief van aard zijn'.

Opvallend is dat het percentage dat in een technische functie werkzaam is bij recent afgestudeerden slechts iets hoger ligt dan voor alle technische opgeleiden. Dat betekent dat de keuze om in een niet-technisch beroep te gaan werken in de meeste gevallen al in een vroeg stadium van de loopbaan wordt gemaakt. Nu zullen niet alle afgestudeerden die werkzaam zijn in een beroep buiten de techniek vrijwillig voor een functie buiten de techniek hebben gekozen. Een gedeelte van de afgestudeerden is mogelijk uitgeweken naar een niet-technisch beroep omdat het niet is gelukt een baan in de techniek te vinden. In hoofstuk 2 bleek immers al dat het percentage van de recent afgestudeerden dat zegt in een andere vakrichting werkzaam te zijn dan waarvoor men is opgeleid toeneemt als de economische situatie ongunstiger wordt. Verder is het ook mogelijk dat werkgevers strenge eisen stellen aan technisch opgeleiden, waardoor sommige technisch opgeleiden niet aan de gestelde functiecriteria voldoen en om die reden uitwijken naar beroepen buiten de techniek.

Aan de andere kant is het ook mogelijk dat er steeds meer sprake is van vraag naar technisch opgeleiden in niet-specifieke technische beroepen. Technische vaardigheden worden door technologische veranderingen ook steeds belangrijker in niettechnische functies. Tabel 4.2 geeft per opleidingstype de verwachte procentuele uitbreidingsvraag vanuit technische, overgangs- en niet-technische beroepen ${ }^{10}$. Het blijkt dat er vooral sprake is van een hoge uitbreidingsvraag vanuit de overgangsberoepen. Dat wijst er op dat er inderdaad sprake is van een toenemende vraag naar

9. Bij de indeling van beroepen in technisch en niet-technisch, worden de opleidingstypes HBO medisch laboratorium en HBO technische bedrijfskunde overigens niet tot de technische opleidingen gerekend maar tot respectievelijk de (para)medische en laboratoriumopleidingen en de economische-administratieve opleidingen.

10. Voor HBO medisch laboratorium en HBO technische bedrijfskunde is de vraag vanuit het technische domein niet bepaald omdat deze opleidingen volgens de indeling waarop deze prognoses gebaseerd worden, respectievelijk tot de paramedische/laboratorium en economische/administratieve richtingen worden gerekend. 
HBO-technici vanuit beroepen die niet zuiver technisch zijn, maar waar technische vaardigheden kennelijk wel van belang zijn.

Het valt echter te verwachten dat door de verwachte tekorten aan technisch opgeleiden de werkgelegenheid voor technisch opgeleiden zich in de toekomst weer steeds meer zal gaan concentreren in het eigen specifieke beroepsdomein (zie ook De Grip e.a. ,1996). De vraag vanuit niet-specifiek technische beroepen kan immers makkelijker worden vervuld door niet-technisch opgeleiden dan de vraag vanuit specifiek technische beroepen. Als technisch opgeleiden als gevolg van de tekorten duurder worden en moeilijker te werven zijn zullen werkgevers er, waar dit mogelijk is, toe over- gaan om mensen met een andere opleidingsachtergrond te rekruteren.

Tabel 4.2

Uitbreidingsvraag vanuit technische, niet-technische en doorstroomberoepen, 1995-2000*

\begin{tabular}{lcrc}
\hline & $\begin{array}{r}\text { Technische } \\
\text { beroepen } \\
\%\end{array}$ & $\begin{array}{r}\text { Overgangs- Niet-technische } \\
\text { beroepen } \\
\%\end{array}$ & $\begin{array}{r}\text { beroepen } \\
\%\end{array}$ \\
\hline HBO technisch laboratorium & 13 & 32 & 19 \\
HBO werktuigbouwkunde & 16 & 26 & 16 \\
HBO elektrotechniek en technische informatica & 17 & 27 & 34 \\
HBO technisch overig & 17 & 27 & 35 \\
HBO haven en vervoer & 15 & 20 & 14 \\
HBO medisch laboratorium &. &. &. \\
HBO technische bedrijfskunde &. & $\cdot$ &. \\
\hline
\end{tabular}

Bron: ROA

* Als percentage van de totale werkgelegenheid voor het betreffende opleidingstype per categorie

\subsection{De arbeidsmarktpositie van technisch opgeleiden werkzaam buiten de techniek}

Als er sprake is van positieve selectie van technisch opgeleiden naar niet-technische beroepen dan zijn niet-technische beroepen aantrekkelijker dan technische beroepen, bijvoorbeeld qua salaris en werkomstandigheden. Als technisch opgeleiden in niet-technische beroepen gaan werken omdat het niet gelukt is om een baan in de techniek te vinden, en er dus sprake is van negatieve selectie, dan valt te verwachten dat niet-technische beroepen juist onaantrekkelijker zijn. In deze paragraaf wordt de arbeidsmarktpositie van technisch opgeleiden werkzaam in technische beroepen vergeleken met de positie van degenen die werken in niet-technische beroepen. De overgangsberoepen worden in deze paragraaf ook tot de technische beroepen gerekend. 
Tabel 4.3

Gemiddeld bruto uurloon van recent afgestudeerden in technische en niet-technische beroepen (standaarddeviatie tussen haakjes), 1995

\begin{tabular}{|c|c|c|c|c|c|}
\hline \multirow[b]{2}{*}{$\begin{array}{l}\text { HBO technisch laboratorium } \\
\text { HLO Chemisch laboratoriumopleiding } \\
\text { HBO Biologische laboratoriumopleiding }\end{array}$} & \multicolumn{2}{|c|}{ Technisch } & \multicolumn{2}{|c|}{ Niet-technisch } & \multirow{2}{*}{$\begin{array}{r}\begin{array}{r}\text { T-toets } \\
\text { voor } \\
\text { verschil }\end{array} \\
0,88 \\
0,60 \\
-\end{array}$} \\
\hline & $\begin{array}{l}17,94 \\
17,77 \\
18,14\end{array}$ & $\begin{array}{l}(3,55) \\
(3,60) \\
(1,88)\end{array}$ & $\begin{array}{r}17,43 \\
17,35 \\
-\end{array}$ & $\begin{array}{l}(3,65) \\
(3,84)\end{array}$ & \\
\hline $\begin{array}{l}\text { HBO (weg-en water)bouwkunde } \\
\text { HTO Bouwkunde } \\
\text { HTO Bouwtechnische bedrijfskunde } \\
\text { HTO Verkeerskunde } \\
\text { HTO Civiele techniek }\end{array}$ & $\begin{array}{l}19,26 \\
18,91 \\
20,33 \\
20,93 \\
19,41\end{array}$ & $\begin{array}{l}(5,15) \\
(6,91) \\
(1,63) \\
(2,55) \\
(2,43)\end{array}$ & $\begin{array}{r}19,82 \\
- \\
21,27 \\
-\end{array}$ & $\begin{array}{l}(3,62) \\
(2,69)\end{array}$ & $\begin{array}{r}0,62 \\
- \\
0,40\end{array}$ \\
\hline $\begin{array}{l}\text { HBO werktuigbouwkunde } \\
\text { HTO Werktuigbouwkunde } \\
\text { HTO Autotechniek }\end{array}$ & $\begin{array}{c}20,06 \\
19,43 \\
18,34\end{array}$ & $\begin{array}{l}(5,88) \\
(4,05) \\
(2,13)\end{array}$ & $\begin{array}{l}19,28 \\
18,54 \\
17,61\end{array}$ & $\begin{array}{l}(5,81) \\
(3,90) \\
(3,33)\end{array}$ & $\begin{array}{l}0,87 \\
0,96 \\
0,92\end{array}$ \\
\hline $\begin{array}{l}\text { HBO elektrotechniek en technische informatica } \\
\text { HTO Elektrotechniek } \\
\text { HTO Informatica }\end{array}$ & $\begin{array}{l}19,32 \\
19,11 \\
20,10\end{array}$ & $\begin{array}{l}(4,11) \\
(4,04) \\
(3,76)\end{array}$ & $\begin{array}{l}18,59 \\
19,01 \\
17,63\end{array}$ & $\begin{array}{l}(4,45) \\
(4,30) \\
(3,76)\end{array}$ & $\begin{array}{l}1,19 \\
0,28 \\
2,63^{\star *}\end{array}$ \\
\hline $\begin{array}{l}\text { HBO technisch overig } \\
\text { HTO Chemische technologie } \\
\text { HAS Levensmiddelentechnologie } \\
\text { HTO Technische natuurkunde }\end{array}$ & $\begin{array}{l}19,77 \\
20,33 \\
19,30 \\
19,64\end{array}$ & $\begin{array}{l}(4,46) \\
(4,74) \\
(2,97) \\
(6,01)\end{array}$ & $\begin{array}{r}17,98 \\
18,00 \\
16,91 \\
-\end{array}$ & $\begin{array}{l}(3,48) \\
(3,40) \\
(2,47)\end{array}$ & $\begin{array}{l}2,70^{\star *} \\
2,23^{\star \star} \\
2,95^{\star \star} \\
-\end{array}$ \\
\hline HBO haven en vervoer & 16,66 & $(6,06)$ & - & & - \\
\hline HBO medisch laboratorium & 18,84 & $(2,78)$ & 17,72 & $(2,75)$ & 1,53 \\
\hline $\begin{array}{l}\text { HBO technische bedrijfskunde } \\
\text { HTO Opleiding bedrijfskader } \\
\text { HTO Technische bedrijfskunde } \\
\text { HEO/HTO Logistiek en Economie }\end{array}$ & $\begin{array}{l}19,56 \\
17,94 \\
19,92 \\
18,67\end{array}$ & $\begin{array}{l}(3,31) \\
(2,90) \\
(3,16) \\
(4,42)\end{array}$ & $\begin{array}{r}18,90 \\
16,95 \\
19,60 \\
-\end{array}$ & $\begin{array}{l}(4,00) \\
(3,74) \\
(4,16)\end{array}$ & $\begin{array}{l}1,72^{*} \\
0,97 \\
1,33 \\
-\end{array}$ \\
\hline $\begin{array}{l}\text { Totaal HBO technisch (excl. deeltijd) } \\
\text { Totaal HBO technisch (incl. deeltijd) }\end{array}$ & $\begin{array}{l}19,36 \\
19,94\end{array}$ & $\begin{array}{l}(4,03) \\
(5,56)\end{array}$ & $\begin{array}{l}18,56 \\
18,84\end{array}$ & $\begin{array}{l}(4,04)^{\star *} \\
(4,40)^{\star \star}\end{array}$ & $\begin{array}{l}3,39^{\star \star} \\
4,14^{\star \star}\end{array}$ \\
\hline
\end{tabular}

Bron: ROA (HBO-Monitor)

* = significant op $10 \%$

** $=$ significant op $5 \%$

Tabel 4.3 geeft het gemiddeld bruto uurloon voor technisch opgeleiden werkzaam in technische en niet-technische beroepen. Gemiddeld genomen verdienen technische opgeleiden die werkzaam zijn in een technisch beroep, iets meer dan degenen die werkzaam zijn in een niet-technisch beroep. Bij veel opleidingstypes is het verschil echter niet significant. De grootste verschillen in gemiddeld uurloon zijn te vinden bij de opleidingstypes HBO werktuigbouwkunde, waar degenen die zijn uitgeweken naar functies buiten de techniek gemiddeld bijna een gulden per uur minder verdienen: HBO technisch overig en HBO medisch laboratorium. Ook met betrekking tot het loon is bij enkele opleidingstypes sprake van grote verschillen tussen de onderliggende opleidingen. Dat geldt bijvoorbeeld voor het opleidingstype HBO elektro- 
techniek en technische informatica. Terwijl het loon voor degenen met een opleiding HTO elektrotechniek gemiddeld genomen vrijwel gelijk is in technische en niettechnische beroepen, is dit verschil bij HTO informatica meer dan twee gulden. Afgestudeerden met een opleiding HBO informatica verdienen meer dan afgestudeerden met de opleiding HTO elektrotechniek zolang ze in de techniek blijven werken.

Verder is de spreiding in het gemiddeld bruto-uurloon tussen afgestudeerden werkzaam in niet-technische beroepen niet systematisch hoger dan tussen afgestudeerden werkzaam in de techniek. De uitwijkers vormen dus geen heterogenere groep dan degenen die in de techniek werkzaam blijven.

Tabel 4.4

Percentage van de recent afgestudeerde technici werkzaam in technische en niet-technische beroepen dat wordt onderbenut, 1995

Technisch

Niet-technisch

\begin{tabular}{|c|c|c|}
\hline $\begin{array}{l}\text { HBO technisch laboratorium } \\
\text { HLO Chemische laboratoriumopleiding } \\
\text { HLO Biologische laboratoriumopleiding }\end{array}$ & $\begin{array}{l}17 \\
17 \\
21\end{array}$ & $\begin{array}{l}38^{* *} \\
37^{* *}\end{array}$ \\
\hline $\begin{array}{l}\text { HBO (weg-en water)bouwkunde } \\
\text { HTO Bouwkunde } \\
\text { HTO Verkeerskunde } \\
\text { HTO Civiele techniek }\end{array}$ & $\begin{array}{l}14 \\
16 \\
11 \\
11\end{array}$ & $\begin{array}{r}11 \\
14 \\
0\end{array}$ \\
\hline $\begin{array}{l}\text { HBO werktuigbouwkunde } \\
\text { HTO Werktuigbouwkunde } \\
\text { HTO Autotechniek } \\
\text { HNO Algemene operationele technologie (AOT) }\end{array}$ & $\begin{array}{l}15 \\
13 \\
36\end{array}$ & $\begin{array}{l}18 \\
14 \\
33\end{array}$ \\
\hline $\begin{array}{l}\text { HBO elektrotechniek en technische informatica } \\
\text { HTO Elektrotechniek } \\
\text { HTO Informatica }\end{array}$ & $\begin{array}{r}10 \\
14 \\
2\end{array}$ & $\begin{array}{l}37^{* *} \\
40^{* *} \\
31^{* *}\end{array}$ \\
\hline $\begin{array}{l}\text { HBO technisch overig } \\
\text { HTO Chemische technologie } \\
\text { HAS Levensmiddelentechnologie } \\
\text { HTO Technische natuurkunde }\end{array}$ & $\begin{array}{l}15 \\
14 \\
21 \\
14\end{array}$ & $\begin{array}{l}41^{\star *} \\
42^{\star *} \\
37 \\
{ }^{*}\end{array}$ \\
\hline HBO haven en vervoer & 30 & 38 \\
\hline HBO medisch laboratorium & 15 & 14 \\
\hline $\begin{array}{l}\text { HBO technische bedrijfskunde } \\
\text { HTO Opl eiding bedrijfskader } \\
\text { HTO Logistiek (management) } \\
\text { HTO Technische bedrijfskunde } \\
\text { HEO/HTO Logistiek en Economie }\end{array}$ & $\begin{array}{l}14 \\
31 \\
10 \\
35\end{array}$ & $\begin{array}{l}26^{* *} \\
51 \\
18^{*} \\
21\end{array}$ \\
\hline $\begin{array}{l}\text { Totaal HBO (excl. deeltijd) } \\
\text { Totaal HBO (incl. deeltijd) }\end{array}$ & $\begin{array}{l}13 \\
13\end{array}$ & $\begin{array}{l}26^{\star *} \\
27^{\star \star}\end{array}$ \\
\hline
\end{tabular}

Bron: ROA (HBO-Monitor)

${ }^{*}=$ significant op $10 \%$-niveau

** $=$ significant op $5 \%$-niveau 
Op basis van de geconstateerde loonverschillen kan geconcludeerd worden dat er over het algemeen sprake is van negatieve selectie naar niet-technische beroepen. $\mathrm{Nu}$ zijn technisch opgeleiden die werkzaam zijn buiten de techniek ook vaak werkzaam in een functie waarvoor het vereiste opleidingsniveau lager is dan HBO. Dat blijkt ook uit tabel 4.4. In totaal wordt $26 \%$ van de technisch opgeleiden die werkzaam zijn in een niet-technisch beroep onderbenut. Van degenen die wel in een technisch beroep werken is dat slecht $13 \%$. Deze verschillen in onderbenutting zijn vooral groot voor de opleidingstypes $\mathrm{HBO}$ technisch laboratorium, HBO elektrotechniek en technische informatica, HBO technisch overig en HBO technische bedrijfskunde. Omdat de lonen van afgestudeerden die in een functie onder hun niveau werkzaam gemiddeld lager liggen dan de lonen van personen die wel een functie op HBO-niveau hebben (zie ook Borghans en Smits, 1996), worden de lagere lonen voor degenen die werkzaam zijn in functie buiten de techniek gedeeltelijk verklaard door het hogere percentage onderbenutting.

Tabel 4.5

Loonvergelijking voor technisch opgeleiden, 1995

\begin{tabular}{lcc}
\hline & Coëfficiënt & T-waarde \\
\hline Niveau beroep & $-0,22$ & $-8,32^{\star \star}$ \\
VBO & $-0,10$ & $-7,46^{\star \star}$ \\
MBO & 0,00 & 0,16 \\
HBO 2e fase/NO & $-0,02$ & $-1,88^{\star}$ \\
Vrouw & 0,05 & $7,96^{\star \star}$ \\
Ervaring & $-0,04$ & $-1,29$ \\
Ervaring & 0,02 & $1,69^{*}$ \\
Technisch beroep & 2,89 & 245,14
\end{tabular}

Bron: ROA (HBO-Monitor)

* $=$ significant op $10 \%$-niveau

** = significant op $5 \%$-niveau

Het is echter ook interessant om na te gaan of de lonen van recent afgestudeerden die in een niet-technisch beroep werkzaam zijn maar wel een functie op HBO-niveau hebben ook gemiddeld minder verdienen dan degenen die een baan in de techniek hebben. Daarom is een loonvergelijking geschat voor technisch opgeleiden, waarbij het loon verklaard wordt uit het vereiste opleidingsniveau voor het beroep dat men uitoefent, het domein van het beroep, technisch of niet-technisch, het geslacht en het aantal maanden werkervaring in de huidige functie. In tabel 4.5 staan de geschatte coëfficiënten van deze loonvergelijking. Het blijkt dat ook wanneer gecorrigeerd wordt voor het vereiste opleidingsniveau personen die in een technische functie werken gemiddeld meer verdienen dan degenen die een niet technischberoep hebben. Ook niet-technische beroepen op HBO-niveau zijn dus in de regel minder aantrekkelijk voor recent afgestudeerde technisch opgeleiden. 
Enkele andere indicatoren voor de aantrekkelijkheid van een functie, is het percentage dat een tijdelijke aanstelling heeft en het percentage dat deeltijdwerk heeft. Uit tabel 4.6 blijkt dat hoewel gemiddeld genomen het percentage van de technisch opgeleiden dat een tijdelijk contract heeft hoger is voor degenen die buiten de techniek werkzaam zijn, dit niet voor alle opleidingstypen geldt. Bij HBO technisch laboratorium en HBO medisch laboratorium komen tijdelijke contracten juist vaker voor onder technisch opgeleiden die werkzaam zijn in een technisch functie. Het beroepsdomein voor HBO medisch laboratorium wordt echter, zoals eerder opgemerkt is, niet tot de technische beroepen gerekend.

Tabel 4.6

Percentage van de recent afgestudeerde technici werkzaam in technische en niet-techinsche beroepen dat tijdelijk werk heeft, 1995

\begin{tabular}{|c|c|c|}
\hline & Technisch & Niet-technisch \\
\hline $\begin{array}{l}\text { HBO technisch laboratorium } \\
\text { HLO Chemische laboratoriumopleiding } \\
\text { HLO Biologische laboratoriumopleiding }\end{array}$ & $\begin{array}{l}68 \\
66 \\
82\end{array}$ & $\begin{array}{r}59 \\
53\end{array}$ \\
\hline $\begin{array}{l}\text { HBO (weg-en water)bouwkunde } \\
\text { HTO Bouwkunde } \\
\text { HTO Bouwtechnische bedrijfskunde } \\
\text { HTO Verkeerskunde } \\
\text { HTO Civiele techniek }\end{array}$ & $\begin{array}{r}40 \\
38 \\
4 \\
48 \\
46\end{array}$ & 53. \\
\hline $\begin{array}{l}\text { HBO werktuigbouwkunde } \\
\text { HTO Werktuigbouwkunde } \\
\text { HTO Aquatische Ecotechnologie } \\
\text { HTO Autotechniek } \\
\text { HNO Algemene operationele technologie (AOT) }\end{array}$ & $\begin{array}{r}52 \\
54 \\
48\end{array}$ & $\begin{array}{r}50 \\
45 \\
47\end{array}$ \\
\hline $\begin{array}{l}\text { HBO elektrotechniek en technische informatica } \\
\text { HTO Elektrotechniek } \\
\text { HTO Informatica }\end{array}$ & $\begin{array}{l}41 \\
51 \\
23\end{array}$ & $\begin{array}{l}50 \\
47 \\
57^{\star *}\end{array}$ \\
\hline $\begin{array}{l}\text { HBO technisch overig } \\
\text { HTO Chemische technologie } \\
\text { HAS Levensmiddelentechnologie } \\
\text { HTO Technische natuurkunde }\end{array}$ & $\begin{array}{l}54 \\
48 \\
66 \\
51\end{array}$ & $\begin{array}{l}69^{\star} \\
76^{\star \star} \\
80\end{array}$ \\
\hline HBO haven en vervoer & 2 & $31^{\star *}$ \\
\hline HBO medisch laboratorium & 69 & $46^{\star}$ \\
\hline $\begin{array}{l}\text { HBO technische bedrijfskunde } \\
\text { HTO Opleiding bedrijfskader } \\
\text { HTO Logistiek (management) } \\
\text { HTO Technische bedrijfskunde } \\
\text { HEO/HTO Logistiek en Economie }\end{array}$ & $\begin{array}{l}42 \\
37 \\
43\end{array}$ & $\begin{array}{r}49 \\
50 \\
49 \\
47\end{array}$ \\
\hline $\begin{array}{l}\text { Totaal HBO (excl. deeltijd) } \\
\text { Totaal HBO (incl. deeltijd) }\end{array}$ & $\begin{array}{l}45 \\
43\end{array}$ & $\begin{array}{l}51^{\star *} \\
50^{* \star}\end{array}$ \\
\hline
\end{tabular}

Bron: ROA (HBO-Monitor)

* $=$ significant bij $10 \%$

$* *=$ signifant bij $5 \%$ 
Hoewel een hoog percentage deeltijdwerk bij een opleidingstype duidt op een ruime arbeidsmarkt voor deze opleiding hoeft deeltijdwerk niet per se negatief beoordeeld te worden. De mogelijkheid om deeltijd te werken wordt door velen als positief gezien. Zo kan het aandeel vrouwen in een bepaalde richting waarschijnlijk een groot deel van de aangetroffen verschillen verklaren. Tabel 4.7 laat zien dat het percentage van de afgestudeerden dat minder dan 36 uur per week werkt in de regel lager is bij degenen die werkzaam zijn in een technisch beroep.

Tabel 4.7

Percentage van de recent afgestudeerde technici werkzaam in technische en niet-technische beroepen dat minder dan 36 uur werkt, 1995

\begin{tabular}{|c|c|c|}
\hline & Technisch & Niet-technisch \\
\hline $\begin{array}{l}\text { HBO technisch laboratorium } \\
\text { HLO Chemische laboratoriumopleiding } \\
\text { HLO Biologische laboratoriumopleiding }\end{array}$ & $\begin{array}{l}5 \\
6 \\
0\end{array}$ & $\begin{array}{l}16^{* *} \\
11 \\
. *\end{array}$ \\
\hline $\begin{array}{l}\text { HBO (weg-en water)bouwkunde } \\
\text { HTO Bouwkunde } \\
\text { HTO Bouwtechnische bedrijfskunde } \\
\text { HTO Verkeerskunde } \\
\text { HTO Civiele techniek }\end{array}$ & $\begin{array}{l}5 \\
8 \\
0 \\
5 \\
1\end{array}$ & 6 \\
\hline $\begin{array}{l}\text { HBO werktuigbouwkunde } \\
\text { HTO Werktuigbouwkunde } \\
\text { HTO Autotechniek } \\
\text { HNO Algemene operationele technologie (AOT) }\end{array}$ & $\begin{array}{l}1 \\
1 \\
3\end{array}$ & $\begin{array}{l}12^{\star \star} \\
7^{\star *} \\
6\end{array}$ \\
\hline $\begin{array}{l}\text { HBO elektrotechniek en technische informatica } \\
\text { HTO Elektrotechniek } \\
\text { HTO Informatica }\end{array}$ & $\begin{array}{l}2 \\
2 \\
2\end{array}$ & $\begin{array}{c}16^{* *} \\
6^{*} \\
36^{\star \star}\end{array}$ \\
\hline $\begin{array}{l}\text { HBO technisch overig } \\
\text { HTO Chemische technologie } \\
\text { HAS Levensmiddelentechnologie } \\
\text { HTO Technische natuurkunde }\end{array}$ & $\begin{array}{r}9 \\
11 \\
3 \\
7\end{array}$ & $\begin{array}{r}14 \\
19 \\
7 \\
.\end{array}$ \\
\hline HBO haven en vervoer & 2 & 0 \\
\hline HBO medisch laboratorium & 9 & 8 \\
\hline $\begin{array}{l}\text { HBO technische bedrijfskunde } \\
\text { HTO Opleiding bedrijfskader } \\
\text { HTO Logistiek (management) } \\
\text { HTO Technische bedrijfskunde } \\
\text { HEO/HTO Logistiek en Economie }\end{array}$ & $\begin{array}{l}3 \\
0 \\
3\end{array}$ & $\begin{array}{l}6 \\
3 \\
8^{*} \\
2\end{array}$ \\
\hline $\begin{array}{l}\text { Totaal HBO (excl. deeltijd) } \\
\text { Totaal HBO (incl. deeltijd) }\end{array}$ & $\begin{array}{l}3 \\
3\end{array}$ & $\begin{array}{l}9^{* *} \\
9^{* *}\end{array}$ \\
\hline
\end{tabular}

Geconcludeerd kan worden dat de positie van technisch opgeleiden die werkzaam zijn in een niet-technisch beroep gemiddeld genomen op meerdere punten slechter 
is dan de positie van afgestudeerden die wel in de techniek werken. Dat duidt er op technisch opgeleiden niet uitwijken naar beroepen buiten de techniek omdat deze beroepen aantrekkelijker zijn. Plausibeler is dat men een niet-technische functie accepteert omdat het niet gelukt is om een technische functie te bemachtigen. Dat kan zijn omdat men op een economisch ongunstig moment de arbeidsmarkt betreedt of omdat vaktechnische vaardigheden tekortschieten om goed in een technisch beroep te kunnen functioneren. Uit het feit dat de gemiddelde lonen in niet-technische beroepen gemiddeld lager liggen kan, zoals eerder opgemerkt, geconcludeerd worden dat er inderdaad sprake is van negatieve selectie. Waarschijnlijk zou men liever werk in de techniek hebben gevonden. Degenen die uitwijken beschikken kennelijk over minder capaciteiten. Uit het feit dat het percentage technisch opgeleiden dat uitwijkt naar niet-technische beroepen toeneemt naarmate de economische situatie op het moment van afstuderen ongunstiger is, blijkt dat een dergelijk tekort aan technische vaardigheden geen absoluut gegeven is. Het weerspiegelt alleen het feit dat werkgevers bij een ruime arbeidsmarkt selectiever kunnen zijn bij de werving.

Figuur 4.1

Intredewerkloosheid van recent afgestudeerden van technische HBO-opleidingen werkzaam in technische en niet-technische beroepen, 1995.

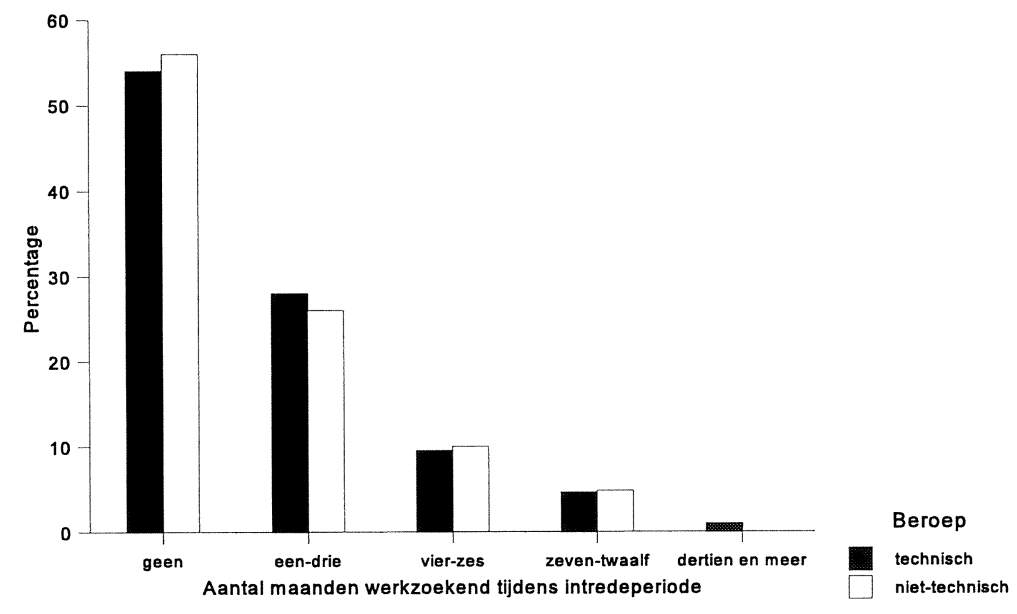

Hoewel het in de regel dus degenen zullen zijn met de minste technische vaardigheden die uitwijken naar banen buiten de techniek, is lang niet iedereen die naar een niet-technisch beroep uitwijkt ook werkelijk niet geschikt voor een technisch beroep. Figuur 4.1 geeft de intredewerkloosheid voor technisch opgeleiden die werkzaam zijn in banen binnen en buiten de techniek. De figuur laat zien dat degenen die werkzaam zijn in een baan buiten de techniek, gemiddeld genomen, korter werkzoe- 
kend zijn geweest dan degenen die werkzaam zijn in een technisch beroep. Dit duidt er op dat mensen inderdaad uitwijken naar banen buiten de techniek omdat het moeilijk is een baan in de techniek te bemachtigen. Door uit te wijken naar een niettechnisch beroep wordt wellicht een lagere werkloosheid vermeden.

Tabel 4.8

Percentage van de recent afgestudeerde technici werkzaam in technische en niet-technische beroepen dat vindt dat de aansluiting opleiding/beroep redelijk tot goed is, 1995

\begin{tabular}{|c|c|c|}
\hline & Technisch & Niet-technisch \\
\hline $\begin{array}{l}\text { HBO technisch laboratorium } \\
\text { HLO Chemische laboratoriumopleiding } \\
\text { HLO Biologische laboratoriumopleiding }\end{array}$ & $\begin{array}{l}85 \\
84 \\
97\end{array}$ & $\begin{array}{l}65^{\star *} \\
62^{*} \\
.^{*}\end{array}$ \\
\hline $\begin{array}{l}\text { HBO (weg-en water)bouwkunde } \\
\text { HTO Bouwkunde } \\
\text { HTO Bouwtechnische bedrijfskunde } \\
\text { HTO Verkeerskunde } \\
\text { HTO Civiele techniek }\end{array}$ & $\begin{array}{l}83 \\
78 \\
86 \\
89\end{array}$ & 84 \\
\hline $\begin{array}{l}\text { HBO werktuigbouwkunde } \\
\text { HTO Werktuigbouwkunde } \\
\text { HTO Autotechniek } \\
\text { HNO Algemene operationele technologie (AOT) }\end{array}$ & $\begin{array}{l}84 \\
83 \\
86\end{array}$ & $\begin{array}{l}67^{\star *} \\
63^{*} \\
79\end{array}$ \\
\hline $\begin{array}{l}\text { HBO elektrotechniek en technische informatica } \\
\text { HTO Elektrotechniek } \\
\text { HTO Informatica }\end{array}$ & $\begin{array}{l}80 \\
75 \\
90\end{array}$ & $\begin{array}{l}76 \\
73 \\
82\end{array}$ \\
\hline $\begin{array}{l}\text { HBO technisch overig } \\
\text { HTO Chemische technologie } \\
\text { HAS Levensmiddelentechnologie } \\
\text { HTO Technische natuurkunde }\end{array}$ & $\begin{array}{l}88 \\
82 \\
88 \\
94\end{array}$ & $\begin{array}{r}55^{\star \star} \\
55^{\star \star} \\
56^{\star \star} \\
.^{\star \star}\end{array}$ \\
\hline HBO haven en vervoer & 77 & 72 \\
\hline HBO medisch laboratorium & 93 & 82 \\
\hline $\begin{array}{l}\text { HBO technische bedrijfskunde } \\
\text { HTO Opleiding bedrijfskader } \\
\text { HTO Logistiek (management) } \\
\text { HTO Technische bedrijfskunde } \\
\text { HEO/HTO Logistiek en Economie }\end{array}$ & $\begin{array}{l}86 \\
89 \\
87\end{array}$ & $\begin{array}{l}88 \\
88 \\
88 \\
83\end{array}$ \\
\hline $\begin{array}{l}\text { Totaal HBO (excl. deeltijd) } \\
\text { Totaal HBO (incl. deeltijd) }\end{array}$ & $\begin{array}{l}83 \\
84\end{array}$ & $\begin{array}{l}78^{* *} \\
78^{* *}\end{array}$ \\
\hline
\end{tabular}

Bron: ROA (HBO-Monitor)

* = significant op $10 \%$-niveau

${ }^{* *}=$ significant op $5 \%$-niveau

De vraag die zich opwerpt in verband met de verwachte toekomstige tekorten is of technisch opgeleiden die werkzaam zijn buiten de techniek nog bereid zijn om terug te keren naar een functie in de techniek. Tabel 4.8 laat zien dat afgestudeerden die in een technisch beroep werkzaam zijn over het algemeen tevredener zijn over de aansluiting tussen de gevolgde opleiding en hun huidige beroep dan afgestudeerden 
die werkzaam zijn in een niet-technisch beroep. Verder blijkt uit tabel 4.9 dat degenen die buiten de techniek werkzaam zijn ook vaker op zoek zijn naar ander werk. Er zijn dus aanwijzingen dat technisch opgeleiden die zijn uitgeweken naar een baan buiten de techniek zeker bereid zijn om alsnog een baan in de techniek te accepteren. Een terugkeer naar de techniek kan echter bemoeilijkt worden doordat de technische vaardigheden ondertussen zijn verouderd.

Tabel 4.9

Percentage van de recent afgestudeerde technici werkzaam in technische en niet-technische beroepen dat op zoek is naar ander werk, 1995

\begin{tabular}{|c|c|c|}
\hline & Technisch & Niet-technisch \\
\hline $\begin{array}{l}\text { HBO technisch laboratorium } \\
\text { HLO Chemische laboratoriumopleiding } \\
\text { HLO Biologische laboratoriumopleiding }\end{array}$ & $\begin{array}{l}37 \\
35 \\
46\end{array}$ & $\begin{array}{l}30 \\
28\end{array}$ \\
\hline $\begin{array}{l}\text { HBO (weg-en water)bouwkunde } \\
\text { HTO Bouwkunde } \\
\text { HTO Bouwtechnische bedrijfskunde } \\
\text { HTO Verkeerskunde } \\
\text { HTO Civiele techniek }\end{array}$ & $\begin{array}{r}16 \\
16 \\
4 \\
19 \\
15\end{array}$ & $\begin{array}{c}33^{\star *} \\
38 \\
38\end{array}$ \\
\hline $\begin{array}{l}\text { HBO werktuigbouwkunde } \\
\text { HTO Werktuigbouwkunde } \\
\text { HTO Autotechniek } \\
\text { HNO Algemene operationele technologie (AOT) }\end{array}$ & $\begin{array}{l}21 \\
21 \\
20\end{array}$ & $\begin{array}{l}34^{* *} \\
36^{* *} \\
47^{\star}\end{array}$ \\
\hline $\begin{array}{l}\text { HBO elektrotechniek en technische informatica } \\
\text { HTO Elektrotechniek } \\
\text { HTO Informatica }\end{array}$ & $\begin{array}{l}19 \\
20 \\
17\end{array}$ & $\begin{array}{l}32^{* *} \\
33 \\
30\end{array}$ \\
\hline $\begin{array}{l}\text { HBO technisch overig } \\
\text { HTO Chemische technologie } \\
\text { HAS Levensmiddelentechnologie } \\
\text { HTO Technische natuurkunde }\end{array}$ & $\begin{array}{l}31 \\
31 \\
30 \\
33\end{array}$ & $\begin{array}{l}57^{\star *} \\
59^{\star \star} \\
56^{\star}\end{array}$ \\
\hline HBO haven en vervoer & 14 & $38^{*}$ \\
\hline $\begin{array}{l}\text { HBO medisch laboratorium } \\
\text { HLO Medische laboratoriumopleiding }\end{array}$ & $\begin{array}{l}19 \\
19\end{array}$ & $\begin{array}{l}23 \\
23\end{array}$ \\
\hline $\begin{array}{l}\text { HBO technische bedrijfskunde } \\
\text { HTO Opleiding bedrijfskader } \\
\text { HTO Logistiek (management) } \\
\text { HTO Technische bedrijfskunde } \\
\text { HEO/HTO Logistiek en Economie }\end{array}$ & $\begin{array}{l}21 \\
21 \\
21\end{array}$ & $\begin{array}{l}33^{* *} \\
23\end{array}$ \\
\hline $\begin{array}{l}\text { Totaal HBO (excl. deeltijd) } \\
\text { Totaal HBO (incl. deeltijd) }\end{array}$ & $\begin{array}{l}21 \\
21\end{array}$ & $\begin{array}{l}33^{* *} \\
33^{* *}\end{array}$ \\
\hline
\end{tabular}

Bron: ROA (HBO-Monitor)

* = significant bij $10 \%$ niveau

** = significant bij $5 \%$ niveau

Geconcludeerd kan worden dat technisch opgeleiden uitwijken naar niet-technische beroepen als de vraag vanuit technische beroepen tekortschiet. Door een niettechnisch beroep te accepteren vermijdt men werkloosheid. Uit het feit dat de lonen 
voor afgestudeerden die werkzaam zijn in een niet-technisch beroep gemiddeld lager zijn dan de lonen van degenen die wel in een technisch beroep werkzaam zijn, blijkt dat er bij schoolverlaters sprake is van negatieve selectie naar niet-technische beroepen. Ook met betrekking tot onderbenutting en tijdelijk werk is de positie van technische opgeleiden die werkzaam zijn in een niet-technische functie ongunstiger.

Door de conjunctuurgevoeligheid van de werkgelegenheid in technische beroepen zijn veel HBO'ers die afstuderen in een economisch ongunstig jaar genoodzaakt uit te wijken naar een niet-technisch beroep. Hoewel er aanwijzingen zijn dat een deel van de mensen die hebben moeten uitwijken wel bereid zijn om alsnog een baan in de techniek te aanvaarden bestaat het gevaar dat toch een aanzienlijk deel van het technisch potentieel verloren gaat. Hierdoor kan het tekort aan technisch opgeleiden nog verder toenemen. 



\section{Conclusies}

In dit hoofdstuk wordt ingegaan op de belangrijkste conclusies van dit rapport. Vervolgens zijn voor elk opleidingstype afzonderlijk de belangrijkste bevindingen bijeengebracht. In dit rapport is de arbeidsmarkt voor technisch opgeleiden op HBOniveau voor zowel de periode 1990-1994 als de periode 1995-2000 nader geanalyseerd. De afgelopen jaren is bij de meeste opleidingstypes nauwelijks sprake geweest van tekorten maar in de komende jaren zullen naar verwachting wel tekorten optreden. Alleen bij de opleidingstypes HBO (weg- en water)bouwkunde en HBO haven en vervoer hebben zich gedurende de periode 1990-1994 knelpunten in de personeelsvoorziening voorgedaan. De arbeidsmarktpositie van afgestudeerden van deze opleidingen is in deze periode ook beter dan van afgestudeerden van de meeste andere technische opleidingen op HBO-niveau. Met name de werkloosheid is lager. Er is dus een duidelijk verband tussen de tekorten die zich bij een opleidingstype voordoen en de arbeidsmarktpositie van recent afgestudeerden van de opleiding. Bij de opleidingstypes $\mathrm{HBO}$ werktuigbouwkunde en $\mathrm{HBO}$ technische bedrijfskunde hebben zich de minste knelpunten in de personeelsvoorziening voorgedaan en ook bij de opleidingstypes HBO technisch laboratorium, HBO elektrotechniek en technische informatica en HBO medisch laboratorium waren weinig knelpunten.

Wel blijkt dat er soms verschillen in arbeidsmarktpositie te zien zijn tussen de verschillende opleidingsrichtingen die onder een bepaald opleidingstype vallen. Zo lijkt bij HBO (weg- en water)bouwkunde de arbeidsmarktpositie van afgestudeerden van de opleiding HTO civiele techniek en HTO bouwkunde wat beter te zijn geweest dan de arbeidsmarktpositie van afgestudeerden van de opleiding HTO verkeerskunde. Het is daarom waarschijnlijk dat de tekorten bij HTO civiele techniek en HTO bouwkunde groter waren dan bij HTO verkeerskunde. Bij HBO elektrotechniek en technische informatica is de arbeidsmarktpositie van degenen met een opleiding in de richting HTO informatica beter dan van mensen die een opleiding HTO elektrotechniek hebben afgerond. Mogelijk was er bij HTO informatica in tegenstelling tot bij HTO elektrotechniek ook in het verleden al enigszins sprake van tekorten. Dat komt overeen met het beeld dat in de media wordt geschetst over deze opleidingsrichting. Tenslotte was bij HBO werktuigbouwkunde de arbeidsmarktpositie van recent afgestudeerden in de richting HTO autotechniek op meerdere punten slechter dan bij HTO werktuigbouwkunde.

Voor de periode 1995-2000 worden met uitzondering van het opleidingstype HBO technische bedrijfskunde wel voor alle opleidingstypes tekorten verwacht. Knelpunten in de personeelsvoorziening zullen zich vooral voordoen in de chemie, in de metaal en elektrotechniek, de energiesector, in de bouw, de handel, in de sector transport opslag en communicatie, in de overige commerciële diensten en de kwartaire dienstverlening. 
De arbeidsmarktpositie van afgestudeerden van technische opleidingen blijkt van jaar tot jaar sterk te fluctueren. Dat geldt ook voor opleidingstypes waar wel sprake was van knelpunten. Met name de werkloosheid fluctueert voor technisch opgeleiden veel sterker dan de werkloosheid voor het gehele HBO. De jaarlijkse fluctuaties in de werkloosheid zijn met name hoog voor de opleidingstypes HBO elektrotechniek en technische informatica, $\mathrm{HBO}$ werktuigbouwkunde en $\mathrm{HBO}$ technische bedrijfskunde. Dus de conjunctuurgevoeligheid van de werkgelegenheid voor HBO-technici biedt een verklaring voor het schijnbaar gelijktijdig voorkomen van werkloosheid onder afgestudeerden en tekorten aan technisch opgeleiden. Hoewel er over de gehele periode genomen tekorten kunnen zijn aan technisch opgeleiden, zoals bijvoorbeeld het geval was bij HBO (weg- en water)bouwkunde, nemen werkgevers bij een conjuncturele neergang toch weinig nieuwe werknemers aan. De recent afgestudeerde HBO-technici wijken dan uit naar beroepen buiten hun eigen vakgebied. Als de economie zich weer herstelt ervaren werkgevers weer opnieuw tekorten.

De arbeidsmarktpositie van technisch opgeleide schoolverlaters uit het HBO die werkzaam zijn in banen buiten de techniek is over het algemeen minder gunstig dan van technisch opgeleiden die werkzaam zijn in banen in de techniek. Ze verdienen gemiddeld genomen iets minder, ze worden vaker onderbenut en hebben vaker een tijdelijke aanstelling. Ten eerste duidt dit er op dat recent afgestudeerde technisch opgeleiden over het algemeen niet uitwijken naar banen buiten de techniek omdat niet-technische beroepen aantrekkelijker zouden zijn. Daarnaast zijn de lagere lonen in niet-technische beroepen ook een aanwijzing dat er sprake is van negatieve selectie naar niet-technische beroepen. Dat wil echter nog niet zeggen dat iedereen die er niet in geslaagd is een beroep in de techniek te vinden over onvoldoende vaktechnische capaciteiten beschikt, maar wel dat degenen die minder capaciteiten hebben eerder moeten uitwijken als de vraag vanuit technische beroepen achterblijft.

Verder zijn er aanwijzingen dat veel technisch opgeleiden die werkzaam zijn in een baan buiten de techniek nog wel op zoek zijn naar een baan in de techniek. Dit gegeven is vooral van belang met het oog op het verwachte tekort aan technisch opgeleiden in de komende jaren. Het is echter de vraag of de technische vaardigheden van iemand die al een tijd in een niet-technische functie werkzaam is inmiddels niet te zeer verouderd zijn om alsnog in een technisch beroep te kunnen functioneren. Het is daarom van groot belang dat in de toekomst wordt voorkomen dat technisch potentieel verloren gaat tijdens een tijdelijke conjuncturele neergang. 


\section{Belangrijkste resultaten per opleidingstype}

\section{HBO technisch laboratorium}

In de periode 1990-1994 was er nauwelijks sprake van knelpunten in de personeelsvoorziening bij dit opleidingstype. Voor de periode 1995-2000 worden echter wel knelpunten verwacht. De werkloosheid onder afgestudeerden van dit opleidingstype is de laatste jaren sterk gestegen. Terwijl in 1991 de werkloosheid lager was dan gemiddeld voor HBO-technisch ligt het werkloosheidspercentage in 1995 flink boven het gemiddelde. Daarbij is ook het percentage afgestudeerden dat buiten het eigen beroepsdomein werkzaam is de afgelopen jaren flink toegenomen. In 1995 is $24 \%$ van de schoolverlaters werkzaam in een beroep onder HBO-niveau en $24 \%$ in een beroep dat niet aansluit op de gevolgde vakrichting. In 1991 was dat nog respectievelijk $6 \%$ en $7 \%$. Naar verwachting zal de arbeidsmarktpositie in de komende jaren verbeteren. Zowel de uitbreidingsvraag als de vervangingsvraag zullen in de periode 1995-2000 erg hoog zijn. De hoge uitbreidingsvraag wordt veroorzaakt door een groei van de werkgelegenheid in beroepen waar personen met een opleiding HBO technisch laboratorium werkzaam zijn. De verwachte tekorten aan personen met een opleiding HBO technisch laboratorium zullen vooral gevoeld worden in de chemie en de kwartaire diensten.

\section{HBO (weg-en water)bouwkunde}

In de periode 1995-2000 zal evenals in de periode 1990-1994 sprake zijn van tekorten aan personen met een opleiding HBO (weg- en water)bouwkunde. De instroom van afgestudeerden op de arbeidsmarkt blijft ook in de komende jaren relatief laag. Daarnaast is er ook sprake van een relatief hoge vervangingvraag als gevolg van de hoge gemiddelde leeftijd van werkenden met deze opleidingsachtergrond. De arbeidsmarktpositie van recent afgestudeerden van deze opleiding was de laatste jaren erg goed. Wel steeg in 1992 en 1993 de werkloosheid onder recent afgestudeerden. Bovendien blijkt de werkloosheid sterk te fluctueren met de conjunctuur. Dus ondanks de tekorten aan afgestudeerden uit deze richting voor de gehele periode heeft een tijdelijke conjuncturele terugval toch invloed op de arbeidsmarkt positie van personen die op dat moment afstuderen. Vanaf 1994 is de werkloosheid onder afgestudeerden weer erg laag. Vooral in de bouw en bij de overheid zal de komenden jaren naar verwachting hinder worden ondervonden als gevolg van tekorten aan afgestudeerden uit deze richting.

\section{HBO werktuigbouwkunde}

Bij dit opleidingstype waren in de jaren 1990-1994 nauwelijks sprake van knelpunten in de personeelsvoorziening. Dat kwam voornamelijk doordat de arbeidsmarktinstroom van recent afgestudeerden in die periode relatief hoog was. De arbeidsmarktpositie was de afgelopen periode dan ook vrij matig. Met name tussen 1992 en 1994 was de werkloosheid onder recent afgestudeerden relatief hoog. Het percentage van de afgestudeerden dat werkzaam was in een baan onder HBO-niveau of 
buiten de eigen richting nam in die periode ook toe. Ook in de periode 1995-2000 zal de arbeidsmarktinstroom hoog blijven. Toch wordt voor deze periode wel een tekort verwacht aan mensen die een opleiding in de richting $\mathrm{HBO}$ werktuigbouwkunde hebben afgerond. Deze tekorten zijn het gevolg van een toegenomen vraag. Zowel de uitbreidingsvraag als de vervangingsvraag zijn de komende jaren hoog. De tekorten die zullen onstaan zullen vooral worden gevoeld in de metaal en elektrotechniek, de handel en de overige commerciële dienstverlening.

\section{HBO elektrotechniek en technische informatica}

Doordat de arbeidsmarktinstroom van afgestudeerden uit de richting HBO elektrotechniek en technische informatica in de periode 1990-1994 erg hoog was, was er ondanks de relatief hoge uitbreidingvraag geen sprake van tekorten bij dit opleidingstype. De werkloosheid onder afgestudeerden uit deze richting was de laatste jaren dan ook erg hoog en lag steeds boven het gemiddelde van alle technisch opgeleiden op HBO-niveau. Bovendien is de werkgelegenheid voor dit opleidingstype erg conjunctuurgevoelig. Wel blijkt de arbeidsmarktpositie van afgestudeerden van de opleiding HTO informatica over de gehele periode wat beter te zijn dan de arbeidsmarktpositie van afgestudeerden uit de richting HTO elektrotechniek. Het is dus mogelijk dat bij HTO informatica wel sprake is geweest van enige tekorten. Dat blijkt ook uit het feit dat met name de werkgelegenheid in de beroepsklasse programmeurs en systeemanalisten, waarin veel mensen met deze opleiding werkzaam zijn, in de afgelopen periode sterk gegroeid is. In 1995 daalt de werkloosheid onder afgestudeerden uit de richting $\mathrm{HBO}$ elektrotechniek en technische informatica sterk. Voor de periode 1995-2000 zal er dan ook sprake zijn van tekorten bij dit opleidingstype. Deze tekorten onstaan doordat de uitbreidingsvraag de komenden jaren erg hoog zal zijn. Vooral in de metaal en elektrotechniek, in de bouw, in de handel, in de sector transport, opslag en communicatie, en in de overige commerciële dienstverlening zal hinder worden ondervonden van de tekorten aan mensen met een opleiding in deze richting.

\section{HBO haven en vervoer}

Bij dit opleidingstype was in de periode 1990-1994 sprake van tekorten en naar verwachting zullen deze tekorten in de periode 1995-2000 blijven bestaan. De tekorten onstaan doordat de arbeidsmarktinstroom van recent afgestudeerden uit deze richting laag is. In de periode 1990-1994 was de vraag naar mensen die een opleiding in de richting $\mathrm{HBO}$ haven en vervoer hadden afgerond nog niet bijzonder hoog. In de komende jaren zullen naar verwachting zowel de uitbreidingsvraag als de vervangingsvraag wel hoog zijn. De tekorten zullen daarom in de periode 19952000 nog groter zijn dan in de voorgaande jaren. Vooral in de sector transport, opslag en communicatie en in de energiesector zal hinder worden ondervonden van deze tekorten. 
HBO medisch laboratorium

Er was in de periode 1990-1994 geen sprake van tekorten bij dit opleidingstype. Toch is gedurende deze gehele periode de werkloosheid onder afgestudeerden uit deze richting vrij laag geweest. Deze lage werkloosheid komt gedeeltelijk voort uit de lage conjunctuurgevoeligheid van de werkgelegenheid voor dit opleidingstype waardoor ook tijdens de conjuncturele neergang, tussen 1992 en 1994 de werkloosheid relatief laag bleef. Wel is in deze periode het percentage afgestudeerden dat in een baan onder HBO-niveau of in een andere vakrichting werkzaam was wat toegenomen. De verwachte tekorten aan mensen met een opleiding in de richting HBO medisch laboratorium zullen vooral voelbaar zijn in de kwartaire dienstverlening.

HBO technische bedrijfskunde

De afgelopen jaren zijn er geen tekorten geweest aan mensen met een opleiding HBO technische bedrijfskunde een ook in de periode 1995-2000 zullen zich naar verwachting geen tekorten voordoen. De arbeidsmarktinstroom was in de periode 1990-1994 hoog en zal ook de komende jaren hoog blijven. Daarbij is de vervangingvraag erg laag door de jonge leeftijdsopbouw van werkenden met deze opleidingsachtergrond. De werkloosheid onder recent afgestudeerden uit deze richting was tussen 1990 en 1995 niet veel hoger dan gemiddeld voor HBO afgestudeerden in de techniek. Wel is het percentage dat werkzaam is in een beroep dat niet aansluit op de gevolgde richting erg hoog. Afgestudeerden kunnen dus werkloosheid vermijden door uit te wijken naar beroepen buiten hun eigen domein. 



\section{Literatuur}

Borghans, L., H. Heijke, Een random-coëfficiënt-model voor het voorspellen van de beroepenstructuur van bedrijfstakken, ROA-W-1994/1, Maastricht, 1994.

Borghans, L., A. de Grip, R. Dekker, A. Matheeuwsen, W. Smits, E. Willems, Methodiek van het Informatiesysteem Onderwijs-Arbeidsmarkt, ROA-W-1995/3, Maastricht, 1995.

Borghans, L., A. de Grip, W. Smits, H. Zuurbier, Beroependomein van opleidingen, ROA, Maastricht , 1996 (verschijnt binnenkort).

Borghans, L., A. de Grip, W. Smits, Beroepsmobiliteit van technisch opgeleiden, OSA-werkdocument D1, Den Haag, 1995.

Borghans, L., A. de Grip, W. Smits, Future developments in the job level and domain of highly skilled workers, paper presented at the symposium 'Naar een transparante arbeidsmarkt voor onderwijs en scholing', Maastricht, juni 1996.

Borghans, L. A. Matheeuwsen, De arbeidsmarkt voor civiel-technisch opgeleiden, ROA-R1995/5, Maastricht, 1995.

Borghans, L., W. Smits, Onderbenutting en beloning van HBO'ers, ROA, Maastricht, 1996, (verschijnt binnenkort).

Centraal Bureau voor de Statistiek, Enquête Beroepsbevolking 1994, Voorburg/Heerlen, 1995.

Centraal Planbureau, Centraal Economisch Plan 1994, Den Haag, 1994.

Centraal Planbureau, Centraal Economisch Plan 1995, Den Haag, 1995.

Loo, P.J.E., van de, G.W.M. Ramaekers, R.K.W. van der Velden, H.M. Zuurbier, De arbeids marktpositie van afgestudeerden van het hoger beroepsonderwijs, HBO-Monitor 1995, HBORaad, Den Haag, 1996.

Matheeuwsen, A.G.M., W. Smits, E.J.T.A. Willems, Trendrapport arbeidsmarkt technisch opgeleiden, ROA-R-1994/12, Maastricht, 1994.

Ministerie van Onderwijs, Cultuur en Wetenschappen, Referentieraming 1995, Zoetermeer, 1995.

Researchcentrum voor Onderwijs en Arbeidsmarkt, De arbeidsmarkt naar opleiding en beroep tot 2000, ROA-R-1995/3, Maastricht, 1995a.

Researchcentrum voor Onderwijs en Arbeidsmarkt, Statistische Bijlage, De arbeidsmarkt naar opleiding en beroep tot 2000, ROA-R-1995/3B, Maastricht, 1995b. 



\section{Appendix 1 Conjunctuurgevoeligheid en werkloosheid}

Om meer inzicht te krijgen in de jaarlijkse fluctuaties in de werkloosheid van recent afgestudeerden van technische opleidingen zijn de volgende vergelijkingen geschat:

$$
U_{i t}=\alpha_{i} \bar{U}_{t}+\varepsilon_{i t}
$$

$$
\Delta U_{i t}=\beta, \Delta \bar{U}_{t}+\varepsilon_{i t}
$$

Waar $U_{i t}$ de werkloosheid onder recent afgestudeerden van opleidingstype $i$, in het enquetejaar $t, t=1991,1992,1993,1994,1995$, en $\bar{U}_{t}$ de gemiddelde werkloosheid onder recent afgestudeerden van het $\mathrm{HBO}$ in het enquetejaar $\mathrm{t}$. Vergelijking (1.a) legt een verband tussen de werkloosheid per opleidingsrichting en de gemiddelde werkloosheid onder alle recent afgestudeerde HBO'ers. $\alpha_{i}$ is de werkloosheidsparameter. Als $\quad \alpha_{i}>1$ dan ligt de werkloosheid voor opleidingstype $i$ systematisch hoger dan het gemiddelde. Als de conjunctuur verslechtert en de werkloosheid toeneemt, neemt de werkloosheid voor opleidingstype $i$ meer dan evenredig toe. Vergelijking (1.b) legt een verband tussen de verandering in de gemiddelde werkloosheid en de verandering in de werkloosheid per opleidingstype $i . \beta_{i}$ is de fluctuatieparameter. Als $\beta_{i}>1$ dan fluctueert de werkloosheid onder recent afgestudeerden van opleidingstype $i$ sterker dan de gemiddelde werkloosheid onder recent afgestudeerde HBO'ers. 


\section{Appendix 2 Correctie werkloosheidfluctuatie voor steekproefonnauwkeurigheid}

De variantie van de jaarlijkse verandering van de werkloosheid wordt gegeven door:

$$
\sum\left(P_{i t}-P_{i t-1}\right)^{2}
$$

Waar $P_{i t}$ het aandeel van afgestudeerden van opleidingstype $i$ dat werkloos is in enquêtejaar $t$. Nu wordt niet de werkelijke werkloosheid waargenomen maar:

$$
\hat{P}_{i t}=P_{i t}+\eta_{i t}
$$

Waar $\hat{P}_{i t}$ het geschatte aandeel van afgestudeerden dat werkloos is op basis van de steekproef en $\eta_{i t}$ de steekproeffout. Hieruit volgt dat:

$$
\sum\left(P_{i t}-P_{i t-1}\right)^{2}=\sum\left(\hat{P}_{i t}-\hat{P}_{i t-1}\right)^{2}-\sum\left(\eta_{i t}-\eta_{i t-1}\right)^{2}
$$

Nu geldt dat

$$
E\left(\eta_{i t}\right)^{2} \approx \frac{\hat{P}_{i t}\left(1-\hat{P}_{i t}\right)}{n_{i t}}
$$

waar $n_{i t}$ is het aantal respondenten van opleidingstype i op tijdstip t. Dus (2.c) kan worden benaderd door:

$$
\sum\left(P_{i t}-P_{i t-1}\right)^{2}=\sum\left(\hat{P}_{i t}-\hat{P}_{i t-1}\right)^{2}-\sum\left(\frac{\hat{P}_{i t}\left(1-\hat{P}_{i t}\right)}{n_{i t}}+\frac{\hat{P}_{i t-1}\left(1-\hat{P}_{i t-1}\right)}{n_{i t-1}}\right)
$$





\section{Appendix 3 Indeling opleidingsrichtingen}

Tabel A.1

Technische opleidingstypes CBS/ROA gegevens en prognoses

\begin{tabular}{ll}
\hline & SOI-codes \\
\hline HBO technisch laboratorium & \\
HBO (weg- en water)bouwkunde & $53100-53199$ \\
HBO werktuigbouwkunde & $53610-53629,53810-53829$ \\
HBO elektrotechniek en technische informatica & $53640-53649,53840-53849$ \\
HBO haven en vervoer & $53650-53659$ \\
HBO medisch laboratorium & $54100-54999$ \\
HBO technische bedrijfskunde & $55200-55299$ \\
& $56200-56299$ \\
\hline
\end{tabular}


Tabel A.2

Technische opleidingstypes en opleidingsrichtingen uit de HBO-Monitor

HBO technisch laboratorium

511040 HAS Laboratoriumtechniek ${ }^{1}$

523010 HLO Chemische laboratoriumopleiding

523030 HLO Biologische laboratoriumopleiding

523040 HLO Analytische proces- en lab. instrumentatie ${ }^{1}$

HBO (weg) en waterbouwkunde

521040 HTO Bouwkunde

521050 HTO Bouwtechnische bedrijfskunde

521200 HTO technische verkeerskunde ${ }^{2}$

521210 HTO Verkeerskunde ${ }^{2}$

521230 HTO Civiele techniek

HBO werktuigbouwkunde

521180 HTO Scheepsbouwkunde

521240 HTO Werktuigbouwkunde

521280 HTO Aquatische Ecotechnologie ${ }^{1}$

521010 HTO Autotechniek

522010 HNO Algemene operationele technologie (AOT)

HBO elektrotechniek en technische informatica

521100 HTO Elektrotechniek

521110 HTO Hogere informatica ${ }^{2}$

521120 HTO Informatica en informatiekunde ${ }^{2}$

HBO technisch overig

521060 HTO Chemische technologie

511050 HAS Levensmiddelentechnologie

521190 HTO Technische natuurkunde

521300 HTO Industrieel produktontwerpen ${ }^{1}$

HBO haven en vervoer

522013 HNO AOT-maritieme bedrijfsvoering ${ }^{1}$

522030 HNO Maritiem officier ${ }^{1}$

HBO medisch laboratorium

523020 HLO Medische laboratoriumopleiding

HBO technische bedrijfskunde

521020 HTO Opl Bedrijfskader

521260 HTO Logistiek (management)

521290 HTO Technische bedrijfskunde

541310 HEO/HTO Logistiek en Economie (economisch.-technisch onderwijs)

${ }^{1}$ Het aantal waarnemingen is te klein om voor deze opleiding afzonderlijk gegevens te kunnen presenteren

2 In de tabellen zijn de opleidingsrichtingen HTO technische verkeerskunde en HTO verkeerskunde en de opleidingsrichtingen HTO hogere informatica en HTO informatica en informatiekunde steeds samengenomen als respectievelijk HTO verkeerskunde en HTO informatica, omdat het aantal waarnemingen te klein is om voor deze opleidingsrichtingen afzonderlijk gegevens te presenteren. 
